\title{
Picoeukaryote distribution in relation to nitrate uptake in the oceanic nitracline
}

\author{
Stuart C. Painter ${ }^{1, *}$, Matthew D. Patey ${ }^{2}$, Glen A. Tarran ${ }^{3}$, Sinhué Torres-Valdés ${ }^{1}$ \\ ${ }^{1}$ National Oceanography Centre, European Way, Southampton SO14 3ZH, UK \\ ${ }^{2}$ Chemistry Department, University of Las Palmas de Gran Canaria, 35017 Las Palmas de Gran Canaria, Spain \\ ${ }^{3}$ Plymouth Marine Laboratory, The Hoe, Prospect Place, Plymouth PL1 3DH, UK
}

\begin{abstract}
We investigated the relationship between picoeukaryote phytoplankton $(<2 \mu \mathrm{m})$ and the deep layer of new production $\left(\mathrm{NO}_{3}{ }^{-}\right.$uptake) in the nitracline of the eastern subtropical North Atlantic Ocean. Indices of $\mathrm{NO}_{3}{ }^{-}$uptake kinetics obtained within the lower $15 \%$ of the euphotic zone demonstrate that subsurface $\mathrm{NO}_{3}{ }^{-}$uptake maxima are coincident with localised peaks in maximum uptake rates $\left(V_{\max }\right)$ and, crucially, with maximum picoeukaryote abundance. The mean rate of $\mathrm{NO}_{3}{ }^{-}$utilization at the nitracline is typically 10 -fold higher than in surface waters despite much lower in situ irradiance. These observations confirm a high affinity for $\mathrm{NO}_{3}{ }^{-}$, most likely by the resident picoeukaryote community, and we conservatively estimate mean cellular uptake rates of between 0.27 and $1.96 \mathrm{fmol} \mathrm{NO}_{3}{ }^{-} \mathrm{cell}^{-1} \mathrm{~h}^{-1}$. Greater scrutiny of the taxonomic composition of the picoeukaryote group is required to further understand this deep layer of new production and its importance for nitrogen cycling and export production, given longstanding assumptions that picoplankton do not contribute directly to export fluxes.
\end{abstract}

KEY WORDS: Nitracline $\cdot$ Picoeukaryote $\cdot$ Nitrate uptake $\cdot$ Subtropical Atlantic Ocean

\section{INTRODUCTION}

In the permanently stratified waters of the oligotrophic ocean, primary production is limited or colimited by the availability of nitrogen (Smith et al. 1986, Moore et al. 2013). At the base of the euphotic zone, however, a number of studies have reported enhanced rates of nitrate uptake indicative of algal growth on a deep nitrate $\left(\mathrm{NO}_{3}{ }^{-}\right)$reservoir (King \& Devol 1979, Le Bouteiller 1986, Lewis et al. 1986, Eppley \& Koeve 1990, Painter et al. 2007). Infrequent observation of this $\mathrm{NO}_{3}{ }^{-}$uptake maximum has not prevented recognition of a deep perennial layer of new production in the subtropical ocean (Ward et al. 1989, Harrison 1990). This layer has also been linked to the export of organic material to the ocean interior (Coale \& Bruland 1987, Small et al. 1987, Kemp et al. 2000) and with a distinct phytoplankton assemblage (the 'shade flora'; Venrick 1982, 1988).

\footnotetext{
*Corresponding author: stuart.painter@noc.ac.uk
}

The depth of the nitracline oscillates vertically on seasonal timescales, being deepest in the summer months and shallowest during winter (Letelier et al. 2004). This vertical migration is primarily driven by changes in irradiance, promoting a biological response that varies over the same timescale. Yet, despite general descriptions of a deep layer of new production having been available for over 20 years, identification of the responsible organisms and explanations for the fate of the consumed $\mathrm{NO}_{3}{ }^{-}$remain equivocal. This is in part driven by our limited understanding of how factors other than slowly changing irradiance intensities impact the lower reaches of the euphotic zone (Letelier et al. 2004, Dore et al. 2008, Dave \& Lozier 2010), but also by limited understanding of picoplankton community structure at depth (Fuller et al. 2006, Worden \& Not 2008, Grob et al. 2011, Kirkham et al. 2013).

() The authors 2014. Open Access under Creative Commons by Attribution Licence. Use, distribution and reproduction are unrestricted. Authors and original publication must be credited. 
Suggestions for the fate of the consumed $\mathrm{NO}_{3}{ }^{-}$ include the production of dissolved organic nitrogen (DON) (Bronk et al. 1994, Bronk \& Ward 2000), luxury uptake (or intracellular storage) by vertically migrating species (Villareal et al. 1993, 1996, 1999) or increased intracellular storage in non-migratory species (i.e. the rate of nutrient transport into the cell exceeds the rate of $\mathrm{NO}_{3}{ }^{-}$reduction to $\mathrm{NO}_{2}{ }^{-} ;$Collos \& Slawyk 1980). In addition, the partial reduction of $\mathrm{NO}_{3}{ }^{-}$to $\mathrm{NO}_{2}{ }^{-}$and excretion to the surrounding water under conditions of light limitation (Raimbault 1986, reviewed by Lomas \& Lipschultz 2006) may be an alternative sink for $\mathrm{NO}_{3}{ }^{-}$. Importantly, these processes may occur with a variable $\mathrm{C}: \mathrm{N}$ stoichiometry or without associated organic carbon synthesis, leading to discrepancies in the interpretation of production and $\mathrm{NO}_{3}{ }^{-}$uptake rates. To this list of explanations may be added heterotrophic bacterial $\mathrm{NO}_{3}{ }^{-}$ uptake (Wheeler \& Kirchman 1986, Kirchman 1994, 2000, Fouilland et al. 2007) which, as well as acting as a sink for $\mathrm{NO}_{3}{ }^{-}$in the absence of photosynthetic production, has important implications when subsequent bacterivory is considered (Zubkov \& Tarran 2008, Hartmann et al. 2012). However, it is far from clear whether heterotrophic bacterial $\mathrm{NO}_{3}{ }^{-}$uptake is widespread in the ocean. Thus, whilst we can be confident that enhanced rates of $\mathrm{NO}_{3}{ }^{-}$uptake do occur at the nitracline, multiple potential mechanisms prevent a simple explanation for the fate of this nitrogen from being identified.

Correct diagnosis ultimately depends on the correct identification of the responsible organisms. It is now well established that primary production in subtropical waters is dominated by picoplankton $(<2 \mu \mathrm{m})$, including the numerically abundant cyanobacteria Prochlorococcus spp. (Chisholm et al. 1988, Partensky et al. 1999) and Synechococcus spp. (Waterbury et al. 1979), which together often account for $>50 \%$ of primary production in these waters (Agawin et al. 2000, Paerl 2000). A significant contribution $(>40 \%$ ) to total primary production and biomass is also made by less numerous eukaryotic phytoplankton (Li 1994, Zubkov et al. 2003, Jardillier et al. 2010). The numerical dominance of Prochlorococcus in surface waters has been linked to a preference for recycled or organic nutrient forms (Zubkov et al. 2003) and studies have revealed high rates of urea utilization associated with this organism (Casey et al. 2007, Painter et al. 2008). Furthermore, an inability to utilize $\mathrm{NO}_{3}{ }^{-}$within cultured ecotypes (Moore et al. 2002, Scanlan \& Post 2008, Partensky \& Garczarek 2010) suggests, as assumed in this study, that this organ- ism can be excluded from consideration as a cause of deep $\mathrm{NO}_{3}^{-}$uptake maxima. However, there have been reports that wild populations of the low light ecotype of Prochlorococcus may be capable of $\mathrm{NO}_{3}{ }^{-}$assimilation or responsive to $\mathrm{NO}_{3}{ }^{-}$concentrations, so this exclusion remains subjective pending definitive confirmation (Casey et al. 2007, Martiny et al. 2009a,b, Malmstrom et al. 2010). The closely related species Synechococcus is known to utilise $\mathrm{NO}_{3}{ }^{-}$(Glover et al. 1988a), but at low irradiances Synechococcus is outcompeted by photosynthetically more efficient eukaryote phytoplankton adapted to blue-violet spectral wavelengths (Wood 1985, Glover et al. 1986, 1987, Prezelin et al. 1989). Consequently, Synechococcus typically assumes a shallower abundance maximum compared to some eukaryotic phytoplankton, which can be noticeably shallower than the nitracline (Murphy \& Haugen 1985). This suggests that Synechococcus can also be excluded from consideration as a cause of deep $\mathrm{NO}_{3}{ }^{-}$uptake maxima, though it should be stressed that Synechococcus responds strongly to near-surface eutrophication events (Glover et al. 1988a).

Eukaryotic phytoplankton are less abundant but more geographically widespread than their prokaryotic counterparts. It has long been known that eukaryotes form a characteristic maximum at the base of the euphotic zone coincident with the nitracline and deep chlorophyll maximum (Cullen 1982, Venrick 1982, Glover et al. 1988b). This maximum is now known to be mainly composed of small $(<2 \mu \mathrm{m})$ (pico)eukaryote cells that are well adapted to conditions of low irradiance and elevated nutrient concentrations. Picoeukaryotes, therefore, are a key candidate group for influencing both the seasonal migration of the nitracline and for causing the widespread deep $\mathrm{NO}_{3}{ }^{-}$uptake maximum. Recently, Fawcett et al. (2011) presented compelling evidence that wild populations of prokaryotic and eukaryotic phytoplankton could be distinguished isotopically, indicating that different plankton groups favour different nutrient reservoirs. In particular, the finding that eukaryotic cells appear isotopically similar to deep ocean $\mathrm{NO}_{3}{ }^{-}$suggests that the deep $\mathrm{NO}_{3}{ }^{-}$ uptake maximum is linked to picoeukaryote communities. In this study, we present results from a series of experiments conducted across the lower $15 \%$ of the euphotic zone of the eastern subtropical North Atlantic in conjunction with observations of the picoplankton community to investigate the potential role of picoeukaryotes in $\mathrm{NO}_{3}{ }^{-}$uptake at the nitracline. 


\section{MATERIALS AND METHODS}

\section{Cruise overview and environmental setting}

All samples were collected in August and September 2011 during a cruise to the eastern North Atlantic Subtropical Gyre. The main working area was nominally located at $26.2^{\circ} \mathrm{N}, 31.1^{\circ} \mathrm{W}$ and broadly defined by a box approximately $160 \times 160 \mathrm{~km}$ in size (see Fig. 1). The environmental setting for our observations was that of a typical subtropical location with a shallow surface mixed layer and a deep euphotic zone. The mixed layer depth $( \pm 1 \mathrm{SD} ; \mathrm{SD}$ used throughout), calculated following de Boyer Montegut et al. (2004), averaged $28 \pm 15 \mathrm{~m}(\mathrm{n}=90)$. The depth of the euphotic zone ( $0.1 \%$ of surface irradiance) was determined from measurements of the water column attenuation coefficient $\left(k_{\mathrm{d}}\right)$, which were obtained from vertical irradiance profiles measured around local noon. The average $k_{\mathrm{d}}$ for the cruise was $0.044 \pm$ $0.002 \mathrm{~m}^{-1}$ (range $0.041-0.048 ; \mathrm{n}=17$ ) and the mean depth of the $0.1 \%$ isolume was $158 \pm 7 \mathrm{~m}$. Water samples for the measurement of nutrient concentrations, picoplankton enumeration, $\mathrm{NO}_{3}{ }^{-}$uptake rates and general environmental characterisation were collected with a Seabird 9/11+ CTD-Niskin rosette package.

\section{Nutrient and chlorophyll measurements}

Nitrate $\left(\mathrm{NO}_{3}{ }^{-}+\mathrm{NO}_{2}^{-}\right)$concentrations were measured using sensitive liquid waveguide capillary techniques providing nanomolar sensitivity with a detection limit of $0.5 \mathrm{nmol} \mathrm{l}^{-1}$ (Patey et al. 2008, 2010), and with standard autoanalyser techniques with a detection limit of $\sim 0.05 \mu \mathrm{mol} \mathrm{l}{ }^{-1}$ (Kirkwood 1996). Both datasets were carefully analysed before being merged. In situations where measurements were available from both instruments (typically the upper nitracline) preference was given to the nanomolar measurements due to the greater sensitivity and precision of the analyses. In this study we defined the nitracline as the depth where $\mathrm{NO}_{3}{ }^{-}$concentration equalled $100 \mathrm{nmol}^{-1}$. This depth was obtained from each individual nutrient profile via linear interpolation where necessary.

Discrete chlorophyll concentrations were measured fluorometrically from $250 \mathrm{ml}$ or $500 \mathrm{ml}$ seawater samples collected from CTD Niskin bottles and filtered onto $25 \mathrm{~mm}(\sim 0.7 \mu \mathrm{m}$ pore size) glass fibre filters following Welschmeyer (1994). All chlorophyll extractions were made in $90 \%$ acetone at $4^{\circ} \mathrm{C}$ overnight with extracts measured using a Turner Trilogy fluo- rometer calibrated against a pure chlorophyll a standard (spinach extract from Sigma Aldrich). CTD chlorophyll fluorescence profiles were linearly calibrated against discrete chlorophyll measurements using the calibration equation $y=2.5766 x-0.0124$ $\left(R^{2}=0.93, n=196\right)$, where $y$ is the calibrated chlorophyll fluorescence profile $\left(\mathrm{mg} \mathrm{m}^{-3}\right)$ and $x$ the measured chlorophyll concentration $\left(\mathrm{mg} \mathrm{m}^{-3}\right)$. No attempt to account for surface quenching of the fluorescence profiles was made.

\section{Primary production and nitrate uptake}

Nitrate and carbon uptake rates were measured with the stable isotopes ${ }^{15} \mathrm{~N}$ and ${ }^{13} \mathrm{C}$ using a dual isotopic labelling approach (e.g. Slawyk et al. 1977). Water samples were collected from 6 depths representing supra-nitracline, nitracline and sub-nitracline waters. We focussed upon depths nominally representing $15 \%$ ( $\sim 50 \mathrm{~m}), 10 \%$ ( $\sim 60 \mathrm{~m}), 5 \%$ ( $\sim 80 \mathrm{~m})$, deep chlorophyll maximum ( 125 m), 0.5\% ( 140 m) and $0.1 \%$ $(\sim 160 \mathrm{~m})$ of surface irradiance. Post-cruise analysis indicated that sampling depths were generally appropriate but that in some cases sampling was deeper than expected. Thus, in reality our samples spanned 13 to $0.01 \%$ (50 to $200 \mathrm{~m}$ ) of surface irradiance.

At each depth, a 21 volume of seawater was carefully measured and added to a clean acid-rinsed polycarbonate bottle. To each bottle, we added $105 \mu \mathrm{mol}$ $\mathrm{I}^{-1}$ of ${ }^{13} \mathrm{C}$-labelled sodium bicarbonate (Cambridge Isotope Laboratories; $4.205 \mathrm{~g}$ per $100 \mathrm{ml}$ deionised water, $\mathrm{pH}$ adjusted with $\mathrm{NaOH}$ ), in addition to a variable concentration of ${ }^{15} \mathrm{~N}$-labelled $\mathrm{KNO}_{3}{ }^{-}$(Cambridge Isotope Laboratories; $5.266 \mathrm{mg}$ per $100 \mathrm{ml}$ deionised water), with additions that ranged from $1 \mathrm{nmol} \mathrm{l}^{-1}$ at supra-nitracline depths to $50 \mathrm{nmol} \mathrm{l}^{-1}$ for samples within the nitracline. ${ }^{13} \mathrm{C}$ additions were made at a level representing $5 \%$ of the dissolved inorganic carbon (DIC) pool $\left(\sim 2100 \mu \mathrm{mol} \mathrm{l}^{-1}\right)$. Efforts were made to keep ${ }^{15} \mathrm{~N}$ spike additions to an absolute minimum to avoid promoting or skewing uptake rates, and the average tracer addition represented just $11 \%$ of the ambient $\mathrm{NO}_{3}{ }^{-}$concentration. All samples were incubated for 4 to $6 \mathrm{~h}$ using a Fytoscope FS130 plant growth chamber (Photon Systems Instruments, www. psi.cz), which provided precise control over temperatures and irradiance levels using cool white LEDs. To provide a graduated light range, sample bottles were still shielded using optical light filters (Lee Filters) and stacked vertically within the growth chamber with the deepest sample at the bottom to provide additional shading. The ambient irradiance level was 

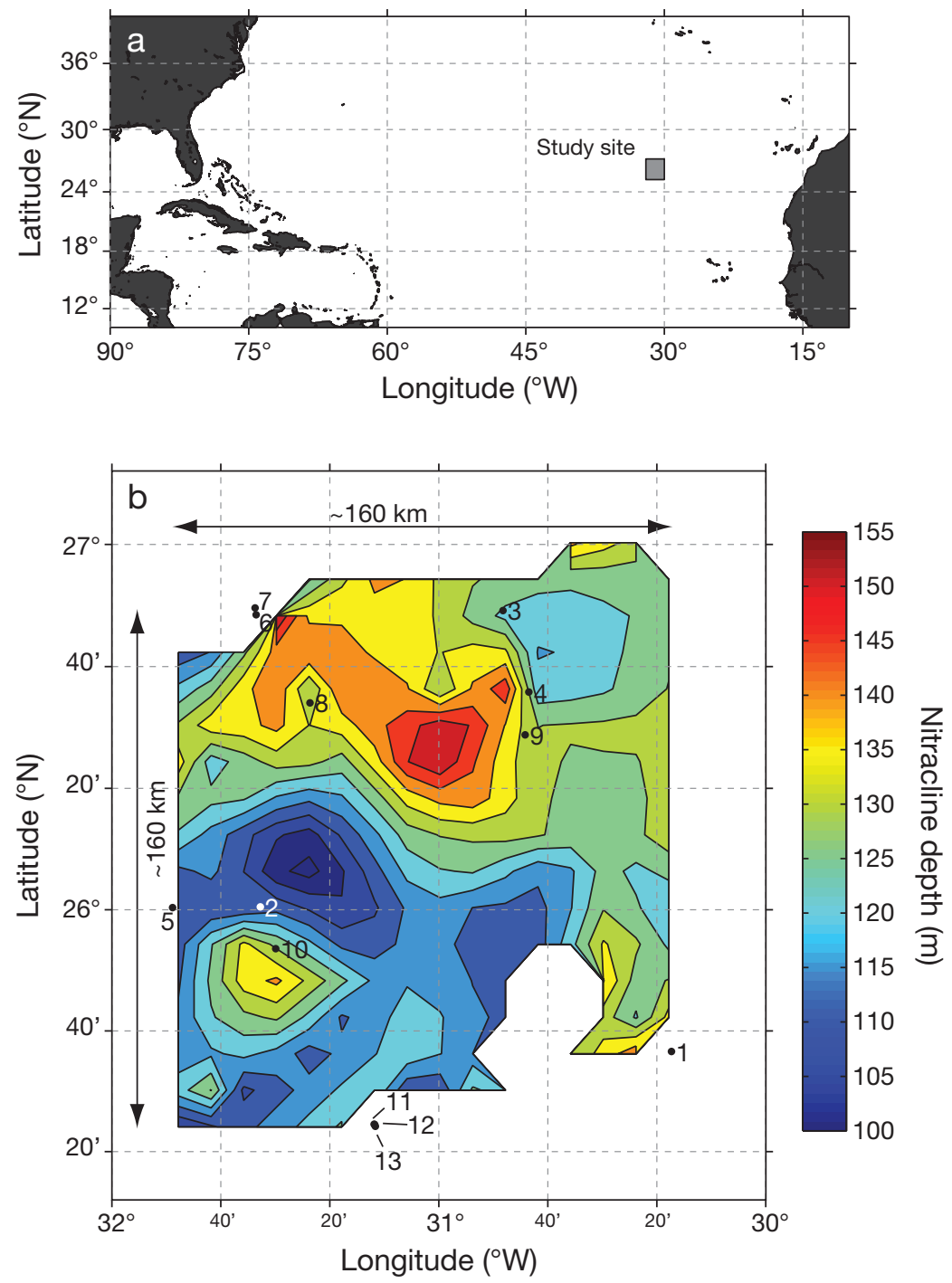

Fig. 1. (a) Subtropical North Atlantic Ocean showing the location of the study site (shaded square) and (b) a finescale map showing the relative position of the stations reported in this study and a contour representation of the nitracline depth during the cruise

set to $170 \mu \mathrm{mol}$ photons $\mathrm{m}^{-2} \mathrm{~s}^{-1}$, equivalent to the typical irradiance intensity at a depth of $59 \mathrm{~m}$. The incubation temperature was held constant for each incubation and set according to the temperature profile on the day of sampling. Typically, there was a 4 to $5^{\circ} \mathrm{C}$ decrease in temperature between the sea surface $\left(>24^{\circ} \mathrm{C}\right)$ and the sampled depths: hence, $20^{\circ} \mathrm{C}$ was often appropriate for sample incubation. After incubation, all samples were gently filtered onto ashed $\left(450^{\circ} \mathrm{C},>6 \mathrm{~h}\right) 25 \mathrm{~mm}$ GF/F filters, rinsed with a weak $(1 \%) \mathrm{HCl}$ solution to remove inorganic carbon and residual incubation water enriched $i{ }^{15} \mathrm{~N} /{ }^{13} \mathrm{C}$ and frozen at $-20^{\circ} \mathrm{C}$. Upon return to shore, all filters were oven-dried $\left(40^{\circ} \mathrm{C}\right)$ overnight and pelleted into tin capsules using a laboratory press, then analysed for carbon and nitrogen abundance and isotopic content on a GV Isoprime mass spectrometer coupled to a Eurovector elemental analyser. All analyses were conducted using a laboratory elemental and isotopic standard (tyrosine) to monitor for instrumental drift. Uptake rates were calculated using the equations of Dugdale \& Wilkinson (1986). The natural abundance of ${ }^{13} \mathrm{C}$ as measured from independent particulate samples was set to $1.079 \%\left(\delta^{13} \mathrm{C}_{\mathrm{VPDB}}=-29.01 \%\right)$. Estimates of daily rates were calculated from hourly uptake rates by multiplying carbon fixation rates by 12 and $\mathrm{NO}_{3}^{-}$uptake rates by 18 to account for dark uptake at a rate $50 \%$ that of daytime rates (Mulholland \& Lomas 2008).

\section{Pico- and nanoplankton enumeration and classification}

Water samples for photosynthetic pico- and nanoplankton enumeration were collected from CTD Niskin bottles and analysed by flow cytometry (FACSort Becton-Dickinson) as described by Zubkov et al. (1998) and Tarran et al. (2006). Briefly, seawater samples were collected in clean $250 \mathrm{ml}$ polycarbonate bottles without fixative and analysed within $3 \mathrm{~h}$ of collection. Samples were refrigerated in the dark at $4^{\circ} \mathrm{C}$ until analysed. Unstained samples were counted at a calibrated flow rate for 3 to 4 min using known concentrations of Beckman Coulter Flowset fluorospheres. Prochlorococcus, Synechococcus, picoeukaryote $(<2 \mu \mathrm{m})$ and nanoeukaryote (approx. 2 to $12 \mu \mathrm{m}$ ) cells were identified based upon group-specific side scattering and orange $(585 \pm 21 \mathrm{~nm})$ and red $(>650 \mathrm{~nm})$ autofluorescence properties. Size classes were determined by filtration as described in Tarran et al. (2006).

\section{Community growth rates}

Community growth rates $(\mu)$ were estimated using the approach suggested by Marañón (2005) where 


$$
\mu=\frac{\mathrm{P}^{\mathrm{B}}}{\mathrm{C}: \operatorname{chl} a}
$$

and where $\mathrm{P}^{\mathrm{B}}$ is the rate of carbon fixed per unit chlorophyll a $\left(\mathrm{mg} \mathrm{C}[\mathrm{mg} \mathrm{chl} a]^{-1} \mathrm{~d}^{-1}\right)$ and the C:chl $a$ ratio ( $\mathrm{mg} \mathrm{C}[\mathrm{mg} \mathrm{chl} \mathrm{a}]^{-1}$ ) is determined as follows. Cell counts of Prochlorococcus, Synechococcus, nanoeukaryotes and picoeukaryotes were first converted to carbon biomass estimates using the cell conversion factors reported by Zubkov et al. $(2000 \mathrm{a}, \mathrm{c})$, Perez et al. (2006) and Tarran et al. (2006); $32 \mathrm{fg} \mathrm{C}$ cell $^{-1}$ for Prochlorocccus, $103 \mathrm{fg} \mathrm{C}^{\mathrm{C}} \mathrm{cell}^{-1}$ for Synechococcus, $1496 \mathrm{fg} \mathrm{C} \mathrm{cell}{ }^{-1}$ for picoeukaryotes and $3350 \mathrm{fg} \mathrm{C}$ $\mathrm{cell}^{-1}$ for nanoeukaryotes. C:chl a ratios were subsequently calculated from estimates of total carbon biomass and corresponding chlorophyll measurements.

\section{RESULTS}

\section{Chlorophyll and nutrient concentrations}

Chlorophyll concentrations were typically $0.05 \mathrm{mg}$ $\mathrm{m}^{-3}$ at the surface but increased to between 0.15 and $0.35 \mathrm{mg} \mathrm{m}^{-3}$ at the deep chlorophyll maximum. The depth of the chlorophyll maximum varied from 105 to $159 \mathrm{~m}$ with a cruise mean depth of $129 \pm 11 \mathrm{~m}$ ( $\mathrm{n}=90$ ), which was $25 \mathrm{~m}$ deeper than the mean depth of the traditional euphotic zone (1\% isolume; $105 \pm$ $4 \mathrm{~m})$. Using the cruise mean attenuation coefficient we calculated that the deep chlorophyll maximum was located at a mean irradiance intensity of $0.39 \%$ of surface irradiance.

The mean $\mathrm{NO}_{3}{ }^{-}$concentration across the upper $100 \mathrm{~m}$ of the water column was $7.1 \pm 1.8 \mathrm{nmol} \mathrm{l}^{-1}$ $(\mathrm{n}=495)$. The mean nitracline depth was $129 \pm 13 \mathrm{~m}$ $(\mathrm{n}=89)$ with individual determinations ranging from 95 to $160 \mathrm{~m}$ depth (Fig. 1b). The mean depth of the nitracline was also clearly deeper than the $1 \%$ light level and located at a depth equivalent to $0.41 \%$ of surface irradiance; thus, the deep chlorophyll maximum and the nitracline were coincident. A northsouth gradient in nitracline depth was evident across our study site with the nitracline being deeper in the north than in the south (Fig. 1b).

\section{Pico- and nanoplankton distribution}

The distribution of pico- and nanoplankton groups is shown in Fig. 2. A clear layered vertical structure was apparent with notable associations between different plankton groups and prominent biogeochemi- cal features. Prochlorococcus, Synechococcus and the nanoeukaryotes were all broadly distributed over the upper $150 \mathrm{~m}$ of the water column. The depth of maximum abundance for each group was located within the upper $100 \mathrm{~m}$ and peak abundances were located at $84 \mathrm{~m}, 68 \mathrm{~m}$ and $34 \mathrm{~m}$ for Prochlorococcus, Synechococcus and the nanoeukaryotes, respectively. In contrast, the peak abundance of picoeukaryotes was located deeper in the water column at $120 \mathrm{~m}$.

The depth of maximum Prochlorococcus abundance (typically $2 \times 10^{5}$ to $3 \times 10^{5}$ cells ml $^{-1}$ ) was coincident with the pronounced subsurface oxygen maximum that is characteristic of the subtropical ocean (Hayward 1994, Riser \& Johnson 2008). Although noticeably shallower, peak Synechococcus abundance (2500 to 4000 cells ml $^{-1}$ ) was also closely associated with the upper slope of the oxygen maximum. The deep chlorophyll maximum was clearly deeper than the depth of peak abundance in Prochlorococcus, Synechococcus and nanoeukaryotic phytoplankton but was coincident with maximum picoeukaryote abundance ( $>2000$ cells ml $^{-1}$ ). Picoeukaryotes therefore appeared predominately responsible for the presence of a deep chlorophyll maximum. Maximum picoeukaryote abundance was also more closely related to the depth of the nitracline than was the case for Prochlorococcus, Synechococcus or the larger nanoeukaryote group. The data does indicate however, that a proportion of the Prochlorococcus community, representing the low light ecotype, was also located at the nitracline.

Prochlorococcus cell abundance dominated at all depths and generally represented $>96 \%$ of total photosynthetic cell abundance (Prochlorococcus + Synechococcus + nanoeukaryotes + picoeukaryotes). Consequently, the mean contribution made by Synechococcus, nanoeukaryote and picoeukaryote cells was generally low $(<4 \%)$, though there were notable vertical patterns. The mean contribution made by Synechococcus reduced 5-fold from $2.1 \pm 0.8 \%$ in the upper $50 \mathrm{~m}$ to $0.38 \pm 0.43 \%$ between 100 and $150 \mathrm{~m}$, with typical contributions of less than $0.1 \%$ at $150 \mathrm{~m}$. In contrast the mean contribution made by picoeukaryotes increased 7 -fold with depth from $0.7 \pm$ $0.35 \%$ in the upper $100 \mathrm{~m}$, to $1.8 \pm 1.3 \%$ between 100 and $150 \mathrm{~m}$ and finally to $5 \pm 3.3 \%$ between 150 and $200 \mathrm{~m}$. Larger nanoeukaryotes cells were a small component of the total photosynthetic cell abundance at all depths with mean contributions of $0.14 \pm$ $0.08 \%$ between 0 and $50 \mathrm{~m}, 0.06 \pm 0.03 \%$ between 75 and $125 \mathrm{~m}$ and $0.26 \pm 0.45 \%$ between 150 and $200 \mathrm{~m}$.

The mean contribution made to total photosynthetic biomass by each group within the upper $100 \mathrm{~m}$ 

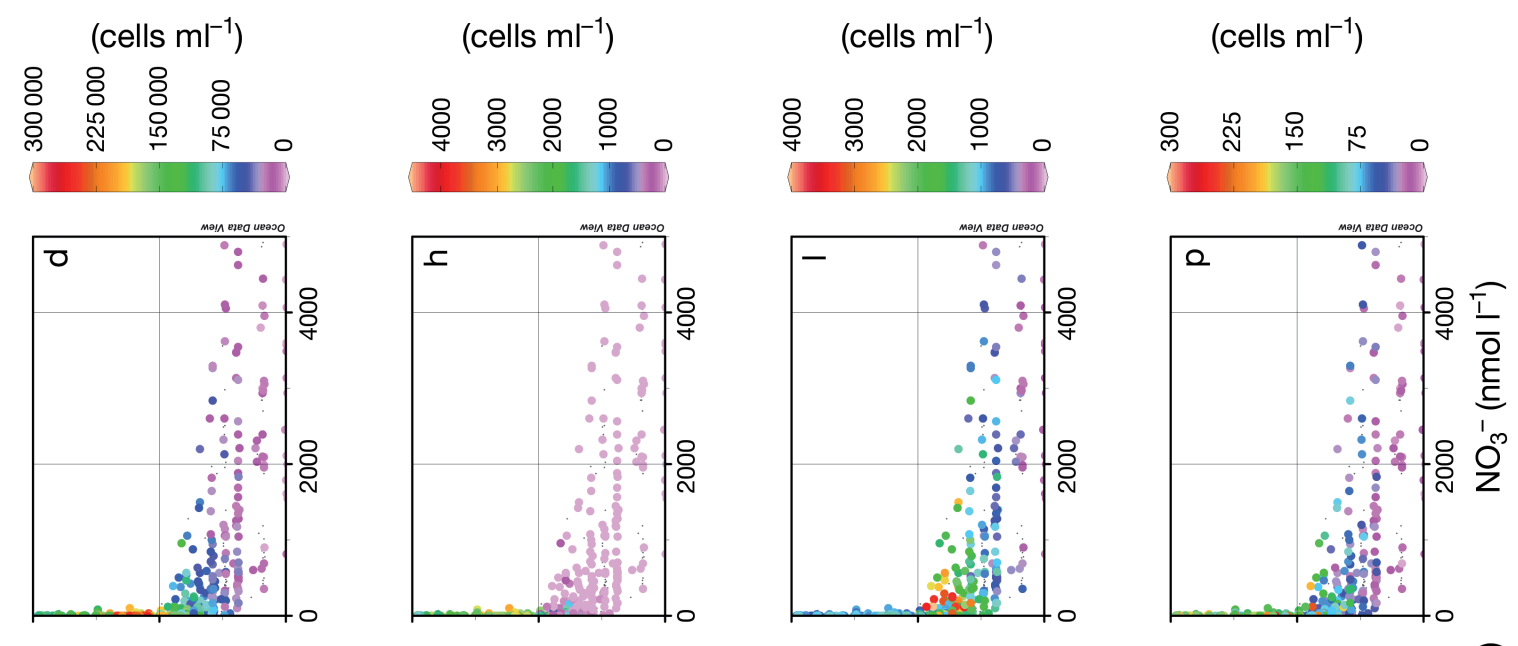

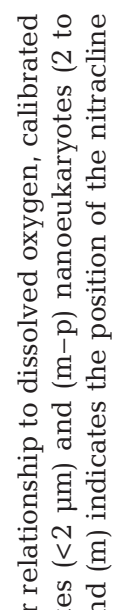
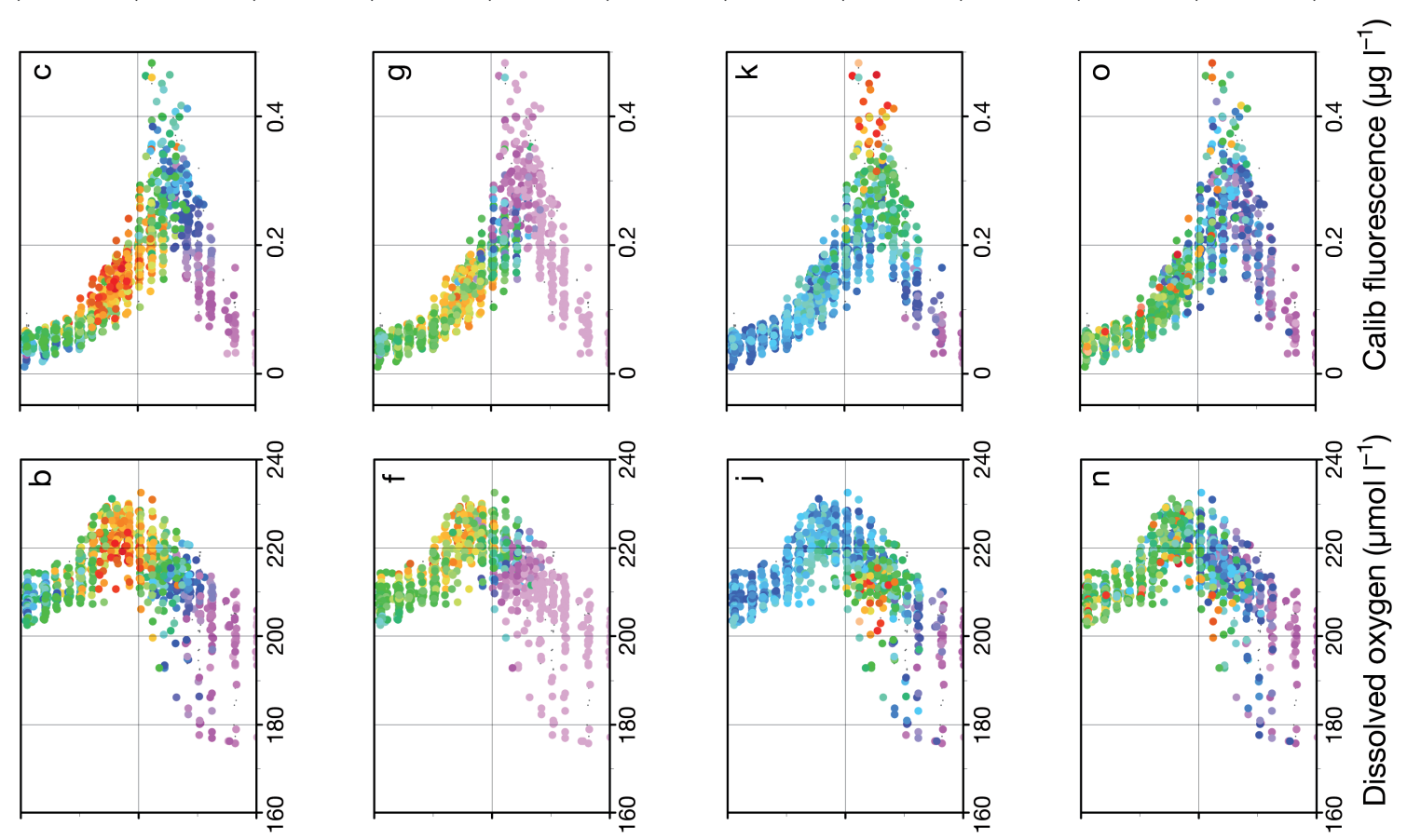

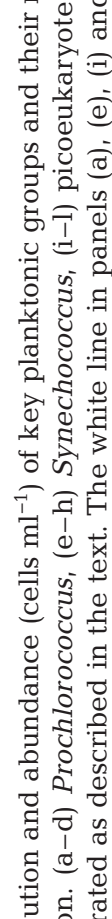
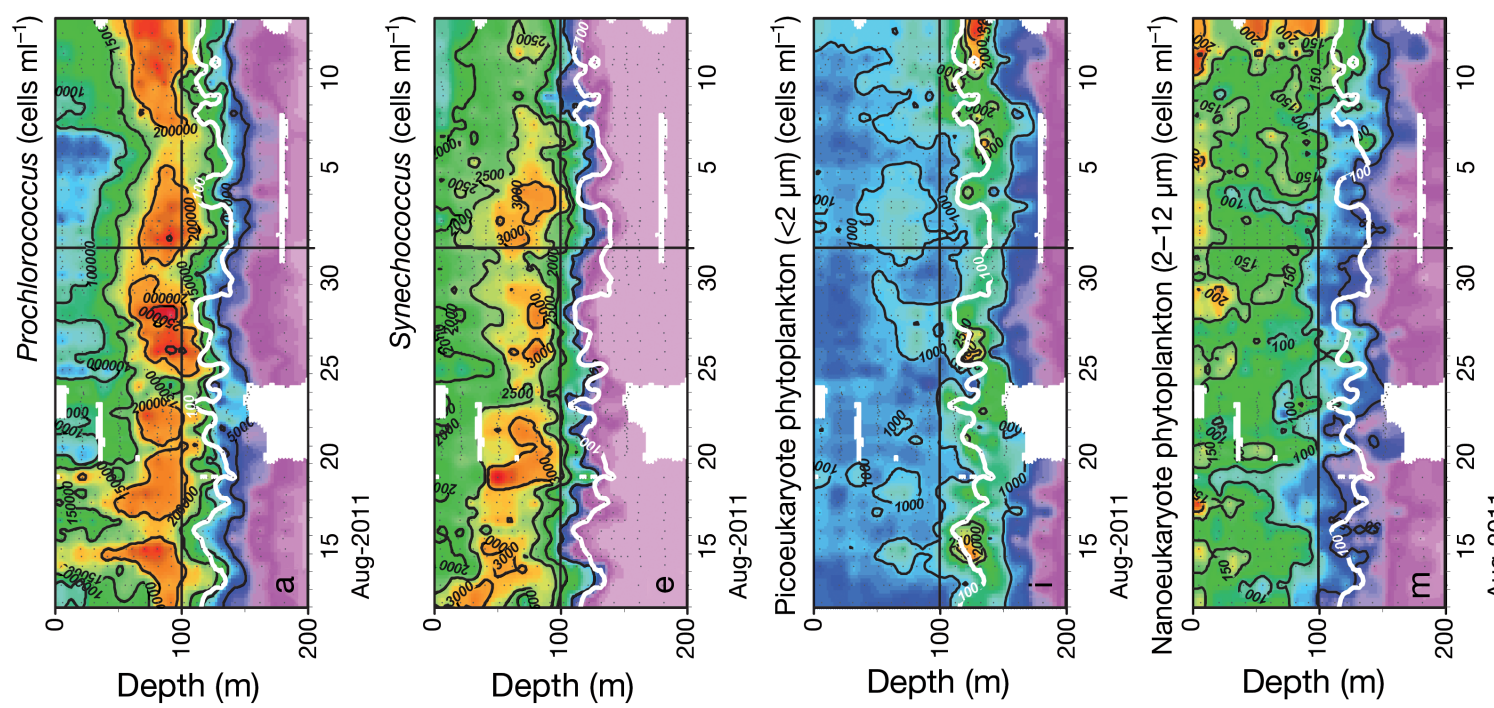

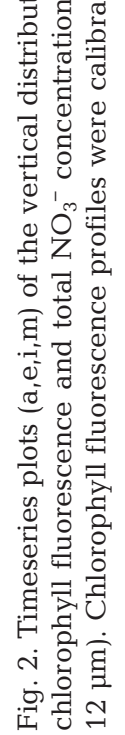


was $4.1 \pm 1.2 \%$ for Synechococcus, $9.5 \pm 3.2 \%$ for nanoeukaryotes, $21.4 \pm 5.6 \%$ for picoeukaryotes and $67.5 \pm 8.9 \%$ for Prochlorococcus. The contributions made by both Synechococcus and the nanoeukaryotes to total biomass decreased only slightly with depth, whereas the dominance shown by picoeukaryotes versus Prochlorococcus switched. In the 100 to $150 \mathrm{~m}$ depth range, picoeukaryotes represented 38.8 $\pm 17.8 \%$ and Prochlorococcus $56.7 \pm 17.6 \%$ of total biomass; there were strong gradients in this region and by $150 \mathrm{~m}$ depth photosynthetic biomass was dominated by picoeukaryote cells. Between 150 and $200 \mathrm{~m}$ picoeukaryotes represented $63.5 \pm 7.5 \%$ of the biomass whilst Prochlorococcus, as the next most dominant contributor, represented $29.7 \pm 8.3 \%$.

\section{Primary production and $\mathrm{NO}_{3}{ }^{-}$uptake}

Vertical profiles of $\mathrm{NO}_{3}{ }^{-}$uptake $\left(\mathrm{\rho NO}_{3}{ }^{-}\right)$, carbon fixation and chlorophyll fluorescence are presented in Fig. 3. Rates of $\mathrm{NO}_{3}^{-}$uptake ranged from 0.03

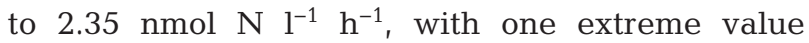

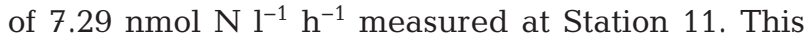
extreme result was coincident with a shallower than normal nitracline (102 $\mathrm{m}$ ) and correspondingly high
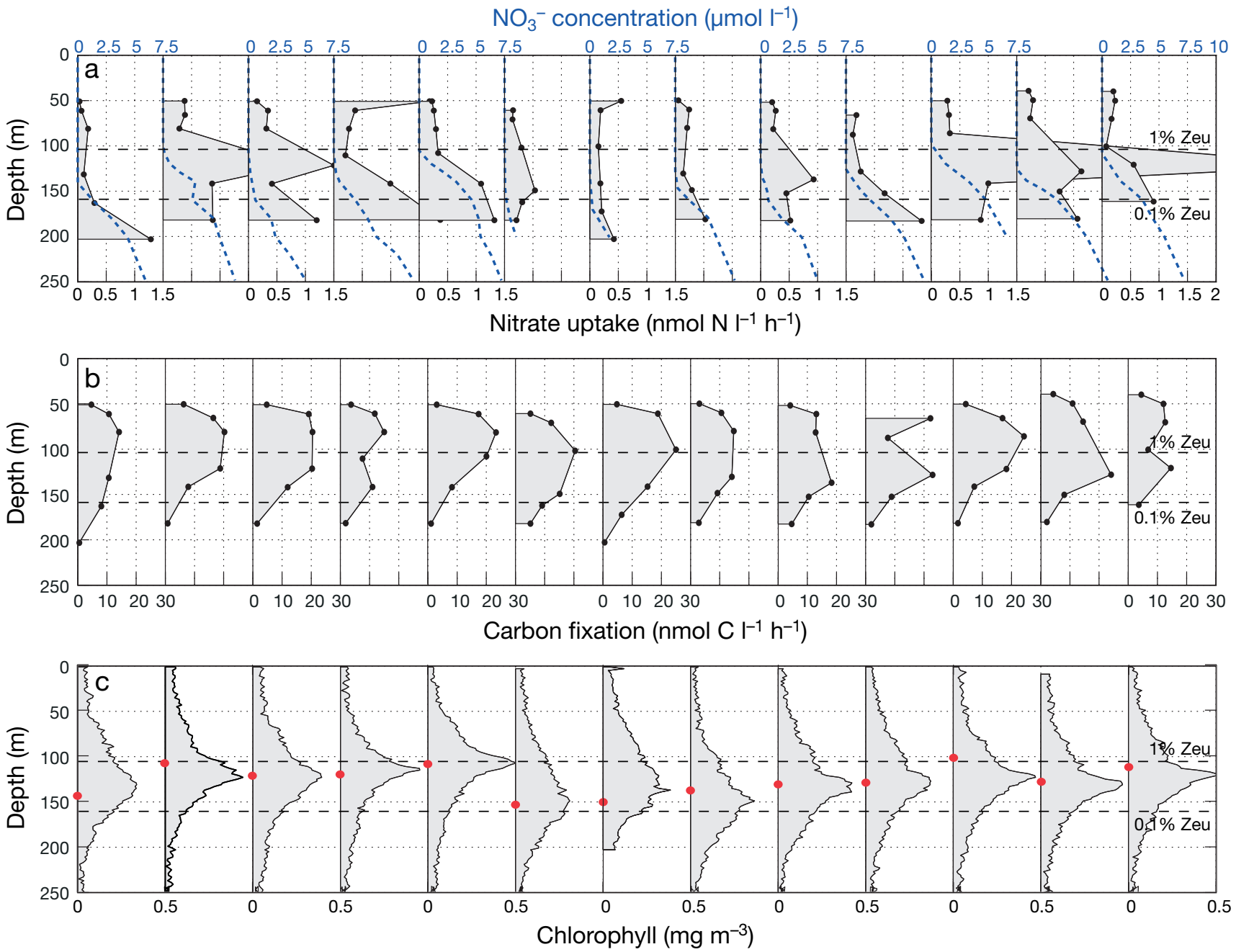

Fig. 3. Vertical profiles of (a) $\mathrm{NO}_{3}{ }^{-}$uptake and $\mathrm{NO}_{3}{ }^{-}$concentration (blue dashed line), (b) carbon fixation and (c) calibrated chlorophyll fluorescence for the 13 sampled stations presented in sequential order. $X$-axis values of sequential panels are identical in each row, with alternate panels labelled for clarity. Note the wide variety of profile shapes evident in the data, including the presence of discrete peaks in $\mathrm{NO}_{3}{ }^{-}$uptake at depths $>100 \mathrm{~m}$ and the tendency for $\mathrm{NO}_{3}{ }^{-}$uptake to increase with depth rather than diminish, coincident with decreases in primary production and chlorophyll. Note also that in most profiles carbon fixation reduces to zero in the depth range 150 to $200 \mathrm{~m}$ whilst $\mathrm{NO}_{3}{ }^{-}$uptake does not, indicating active $\mathrm{NO}_{3}{ }^{-}$uptake in the absence of autotrophic carbon fixation. The grey shading is used to accentuate the profile shape and indicate the zero point for each profile. In panel (c) the depth of the nitracline in each profile is represented by the red circle. Cruise mean depths of $1 \%(1 \%$ Zeu $)$ and $0.1 \%(0.1 \%$ Zeu $)$ irradiance horizons denoted by horizontal dashed lines in all panels 
$\mathrm{NO}_{3}{ }^{-}$concentrations $\left(\sim 1.3 \mu \mathrm{mol} \mathrm{l} \mathrm{l}^{-1}\right)$ at a relatively high position in the water column and therefore under a relatively high irradiance. Although this result is not representative of the bulk of our observations it does give some indication of the potential for rapid $\mathrm{NO}_{3}{ }^{-}$utilization following the uplift of the nitracline into shallower waters (Goldman \& McGillicuddy 2003, Karl et al. 2003). The maximum $\mathrm{NO}_{3}{ }^{-}$uptake rate for a given profile was located within the nitracline, though differences in the depth of the nitracline between stations resulted in a variable depth of the uptake maximum. $\mathrm{NO}_{3}{ }^{-}$uptake rates from supranitracline depths $(<100 \mathrm{~m})$ were generally the lowest measured $\left(<0.3 \mathrm{nmol} \mathrm{N} \mathrm{^{-1 }} \mathrm{h}^{-1}\right)$ and reflective of the low ambient $\mathrm{NO}_{3}{ }^{-}$concentrations found at these shallower depths.

Rates of carbon fixation ranged from 0.52 to $24.99 \mathrm{nmol} \mathrm{C} \mathrm{l}^{-1} \mathrm{~h}^{-1}$ (equivalent to 0.006 to $0.3 \mathrm{mmol}$ $\left.\mathrm{C} \mathrm{m}^{-3} \mathrm{~d}^{-1}\right)$. However, the purposeful omission of shallow $(<50 \mathrm{~m})$ production measurements from our experimental design accentuates the presence of a subsurface maximum in carbon fixation between 50 and $150 \mathrm{~m}$ in all profiles. This maximum ranged from 14.1 to $25 \mathrm{nmol} \mathrm{C}^{-1} \mathrm{~h}^{-1}$ (0.17 to $0.3 \mathrm{mmol} \mathrm{C} \mathrm{m}^{-3} \mathrm{~d}^{-1}$ ) on individual profiles with an average rate of $19.8 \pm$ $4.1 \mathrm{nmol} \mathrm{C} \mathrm{l}^{-1} \mathrm{~h}^{-1}\left(0.24 \pm 0.05 \mathrm{mmol} \mathrm{C} \mathrm{m}^{-3} \mathrm{~d}^{-1}\right)$. Rates decreased towards zero at greater depths. Though there is evidently some variability in the depth of this deep production maximum, there does not appear to be any consistent relationship to the corresponding $\mathrm{NO}_{3}{ }^{-}$uptake profiles and it is not the case that high carbon fixation and high $\mathrm{NO}_{3}{ }^{-}$uptake occur at the same depth.

The corresponding profiles of chlorophyll fluorescence are also presented in Fig. 3c. Comparison to both the nitracline depth and to the profiles of $\mathrm{NO}_{3}{ }^{-}$ uptake indicated that the deep chlorophyll maximum was occasionally, but not always, associated with a peak in $\mathrm{NO}_{3}{ }^{-}$uptake, suggesting that simply using chlorophyll fluorescence to indicate where maximum $\mathrm{NO}_{3}{ }^{-}$uptake is likely to occur can be inappropriate.

In Table 1 we present carbon and $\mathrm{NO}_{3}^{-}$uptake rates, and chlorophyll and $\mathrm{NO}_{3}{ }^{-}$concentrations integrated (trapezoidal method) between 50 and $180 \mathrm{~m}$; i.e. the specific part of the water column that includes the transition from high light/low nutrient to low light/high nutrient conditions and the processes that occur within it. Integrated chlorophyll concentrations calculated from trapezoidal integrations of discrete bottle chlorophyll samples were broadly similar between stations, ranging from 21.85 to $29.73 \mathrm{mg} \mathrm{m}^{-2}$ with a mean of $24.69 \pm 2.6 \mathrm{mg} \mathrm{m}^{-2}$. Integrated $\mathrm{NO}_{3}{ }^{-}$ concentrations varied almost 23 -fold between sta-

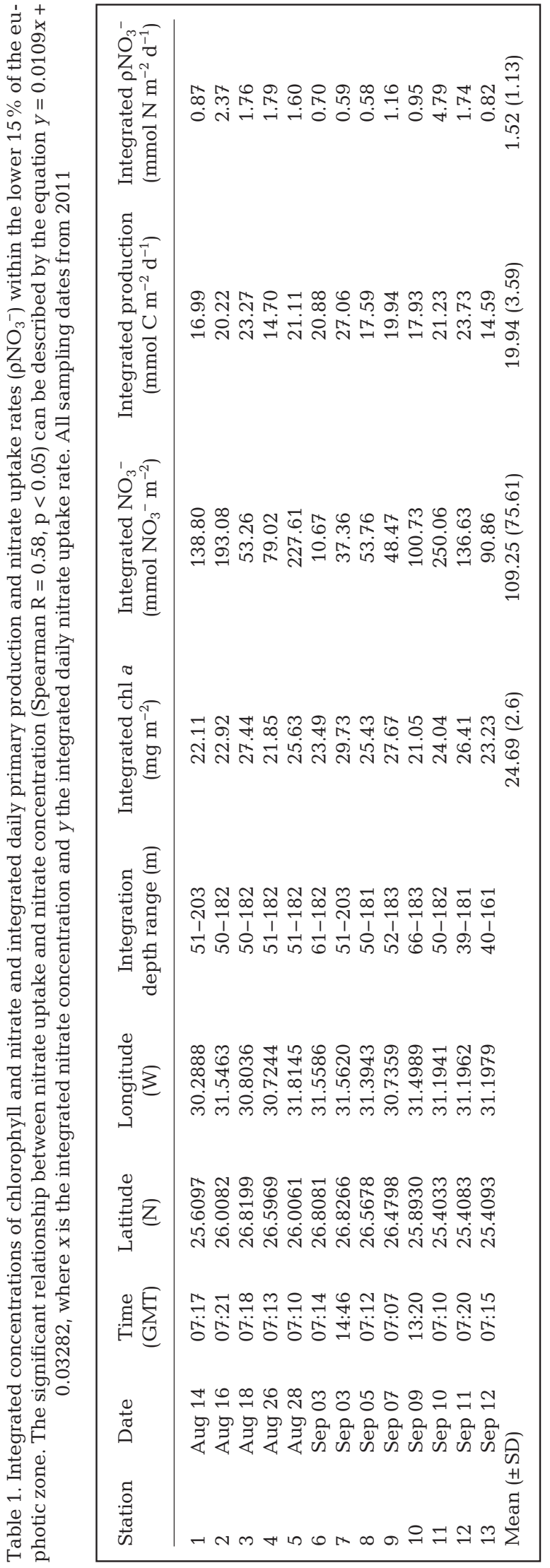


tions, with values of 10.7 to $250 \mathrm{mmol} \mathrm{NO}_{3}{ }^{-} \mathrm{m}^{-2}$. This variability was driven by undulations in $\mathrm{NO}_{3}{ }^{-}$contours within the lower reaches of the water column examined here. The mean integrated $\mathrm{NO}_{3}{ }^{-}$concentration was $109 \pm 75 \mathrm{mmol} \mathrm{m}^{-2}$. Integrated production rates varied almost 2-fold and ranged from 14.6 to $27 \mathrm{mmol} \mathrm{C} \mathrm{m}{ }^{-2} \mathrm{~d}^{-1}$ with a mean production rate of 20 $\pm 3.5 \mathrm{mmol} \mathrm{C} \mathrm{m}^{-2} \mathrm{~d}^{-1}$. Given that a significant fraction of the euphotic zone was omitted, we still captured a significant proportion of the production (as typical productivity rates for these waters are in the range of 5 to $40 \mathrm{mmol} \mathrm{C} \mathrm{m}{ }^{-2} \mathrm{~d}^{-1}$; Marañón et al. 2000, Perez et al. 2006, Poulton et al. 2006). Integrated $\mathrm{NO}_{3}{ }^{-}$uptake rates varied 8fold between stations, from 0.58 to 4.79 mmols $\mathrm{N} \mathrm{m}^{-2} \mathrm{~d}^{-1}$ with a mean of $1.5 \pm 1.1 \mathrm{mmol} \mathrm{N} \mathrm{m}^{-2} \mathrm{~d}^{-1}$. Depth-integrated values of $\mathrm{NO}_{3}^{-}$uptake and $\mathrm{NO}_{3}{ }^{-}$concentration were significantly correlated (Spearman $\mathrm{R}=0.58, \mathrm{p} \leq$ $0.05)$. It is noteworthy that the variability in production was substantially lower than the variability in $\mathrm{NO}_{3}{ }^{-}$ uptake or $\mathrm{NO}_{3}{ }^{-}$concentration, which suggests that $\mathrm{NO}_{3}{ }^{-}$uptake was decoupled from production.

\section{Relationship between irradiance and $\mathrm{NO}_{3}{ }^{-}$uptake}

Spatial and temporal variability is likely to influence our dataset; thus, to more broadly interpret the results we pooled the data and plotted key variables against irradiance (Fig. 4). In so doing, a fundamental difference in the pattern of $\mathrm{NO}_{3}{ }^{-}$versus carbon uptake emerged. In the case of carbon, both the specific uptake rates (v) (Fig. 4a) and the absolute uptake rates ( $\rho$ ) (Fig. 4e) indicated a carbon uptake maximum above the nitracline at approximately the $1 \%$ irradiance level and a steady decrease towards zero at lower irradiance levels. In contrast, $\mathrm{NO}_{3}{ }^{-}$specific uptake rates increased with depth into the nitracline (Fig. 4b), and in terms of absolute uptake rates, $\mathrm{NO}_{3}{ }^{-}$uptake increased almost 10 -fold from $\sim 0.2 \mathrm{nmol}$

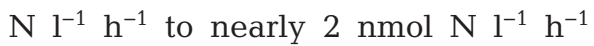
(Fig. 4f), though in both cases there was an increase in variability within the datasets at lower irradiance levels. The presence of a carbon uptake maximum at $\sim 1 \%$ irradiance level appeared as a pronounced and consistent feature in our data, caused by greater carbon fixation per unit biomass rather than an increase in biomass (which decreased only slightly with reducing irradiance intensity, i.e. depth). The absence of a similar peak in $\mathrm{NO}_{3}{ }^{-}$uptake coincident with the carbon fixation maximum indicated that this productivity maximum was fuelled by nutrients other than $\mathrm{NO}_{3}{ }^{-}$, most likely recycled nitrogen, and supports the conclusion that production and $\mathrm{NO}_{3}{ }^{-}$uptake are decoupled.
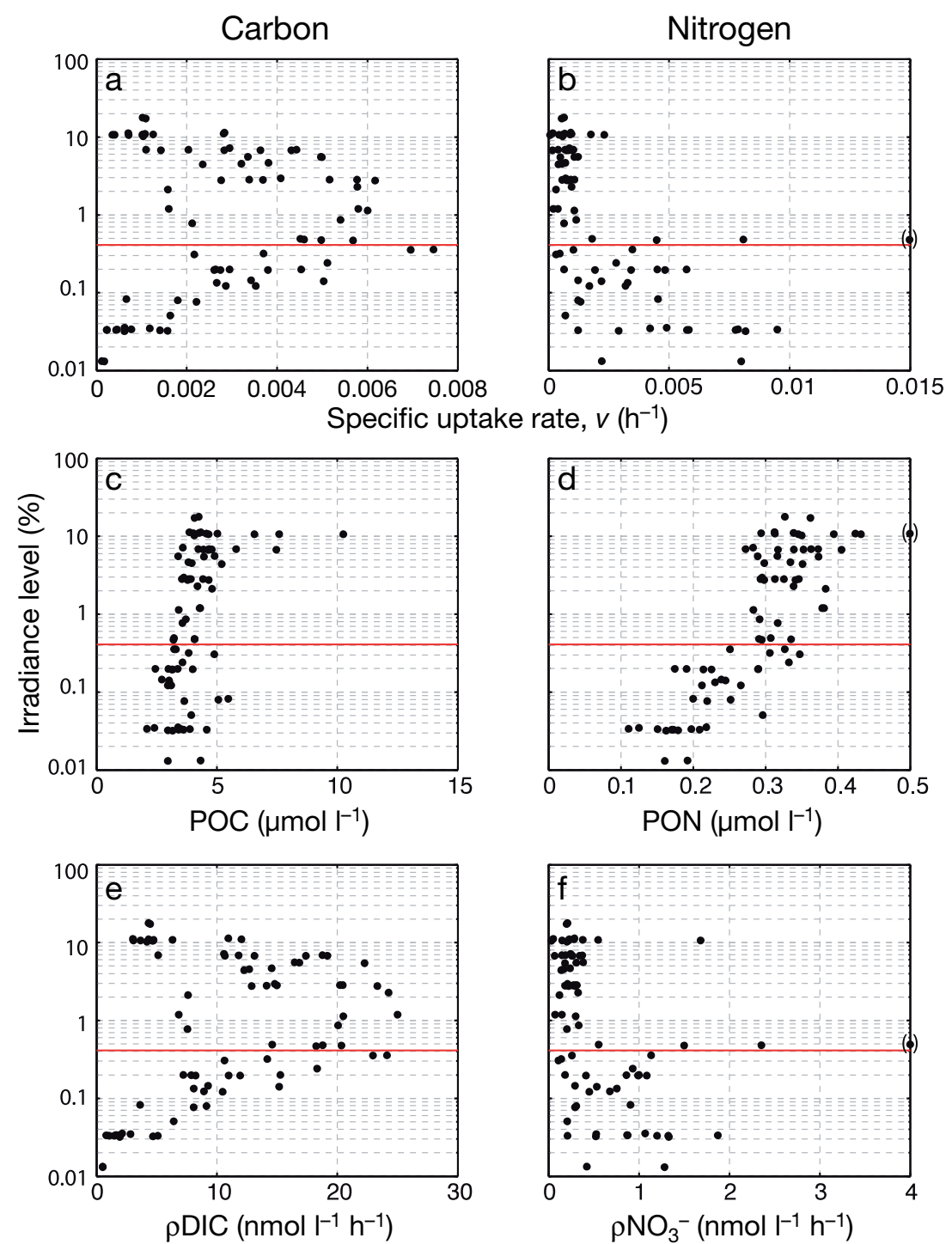

Fig. 4. Irradiance profiles of (a) dissolved inorganic carbon-specific uptake rate, (b) nitrate-specific uptake rate, (c) particulate organic carbon (POC), (d) particulate organic nitrogen (PON), (e) dissolved inorganic carbon (DIC) uptake rate and (f) $\mathrm{NO}_{3}{ }^{-}$uptake rate. The horizontal red line in each panel represents the cruise mean depth of the nitracline $(129 \pm 13 \mathrm{~m})$. In the right hand panels, data points lying beyond the axis limits are indicated with parentheses 
Profiles of POC and PON concentration both showed a steady decrease with depth, from values of $\sim 5 \mu \mathrm{mol} \mathrm{C}{ }^{-1}$ and $\sim 0.4 \mu \mathrm{mol} \mathrm{N}{ }^{-1}$ at the shallowest sampling horizon to values of $\sim 3 \mu \mathrm{mol} \mathrm{C}^{-1}$ and $<0.2 \mu \mathrm{mol} \mathrm{N}^{-1}$ at depth (Fig. 4c,d). Interestingly, the reduction in PON concentration with depth was more pronounced than the corresponding reduction in POC concentration, supporting general observations that the remineralization length scales for $\mathrm{C}$ and $\mathrm{N}$ are different (Longhurst \& Harrison 1989, Ono et al. 2001). Particulate organic $\mathrm{C}: \mathrm{N}$ ratios, and the $\mathrm{C}: \mathrm{NO}_{3}{ }^{-}$ uptake ratio, augmented with additional data from separate ${ }^{15} \mathrm{~N} /{ }^{13} \mathrm{C}$ uptake experiments conducted during this cruise (Painter et al. 2013), showed that elevated C:N ratios relative to the Redfield ratio $(\sim 7: 1$; Redfield 1958, Redfield et al. 1963) were common throughout the entire water column (Fig. 5a). Particulate C:N ratios of $\sim 14$ were typical in shallow waters but the ratio decreased to values of $\sim 12$ at the base of the euphotic zone between 1 and $0.1 \%$ PAR, most likely in response to increased nutrient concentrations. A substantial increase in the $\mathrm{C}: \mathrm{N}$ ratio (to values >20) was evident below $160 \mathrm{~m}$ depth. Elevated C:N ratios in organic matter is characteristic of subtropical waters and considered indicative of sub-optimal plankton growth rates in response to a low nutrient input history (Goldman et al. 1979, Martiny et al. 2013).

In the absence of true $\mathrm{C}: \mathrm{N}$ uptake ratios we present the ratio of $\mathrm{C}: \mathrm{NO}_{3}{ }^{-}$uptake, which provides qualitative information on the relative importance of $\mathrm{NO}_{3}{ }^{-}$ for production. The profile of the $\mathrm{C}: \mathrm{NO}_{3}{ }^{-}$uptake ratio (black dots in Fig. 5b) revealed a distinct maximum around $80 \mathrm{~m}$ depth indicative of a productivity maximum that was not fuelled by $\mathrm{NO}_{3}{ }^{-}$. Rather, this feature must have been driven by alternative nutrients such as ammonium and other recycled forms. Within the broader context of other observations made during this cruise (red dots in Fig. 5), the $\mathrm{C}: \mathrm{NO}_{3}{ }^{-}$ratios observed at $80 \mathrm{~m}$ were broadly comparable to those ratios seen in the upper $40 \mathrm{~m}$ of the euphotic zone. Thus, the apparent $\mathrm{C}: \mathrm{NO}_{3}{ }^{-}$minimum seen at $\sim 50 \mathrm{~m}$ must be viewed carefully as it provides a false impression of the vertical variability in $\mathrm{C}: \mathrm{NO}_{3}{ }^{-}$ratios due to the absence of data from shallower depths. The ratio of specific uptake $(v)$, also shown in Fig. 5c (note $\log$ scale), revealed a gradual decrease with depth and noticeably lower ratios at depths $>180 \mathrm{~m}$. We interpret this as being due to the influence of increased detrital material at depth, which also agrees with the rather dramatic increase in the $\mathrm{C}: \mathrm{N}$ ratio of the particulate material at the same depth (Fig. 5a).

\section{Relationship between picoeukaryotes and $\mathrm{NO}_{3}{ }^{-}$uptake}

The relationship between picoeukaryote abundance and $\mathrm{NO}_{3}{ }^{-}$uptake relative to both sampling depth and ambient $\mathrm{NO}_{3}{ }^{-}$concentration is shown in Fig. 6a,b. Under the assumption that picoeukaryotes consumed the majority of the available $\mathrm{NO}_{3}{ }^{-}$, we identified 3 distinct clusters within the data related to 3 depth
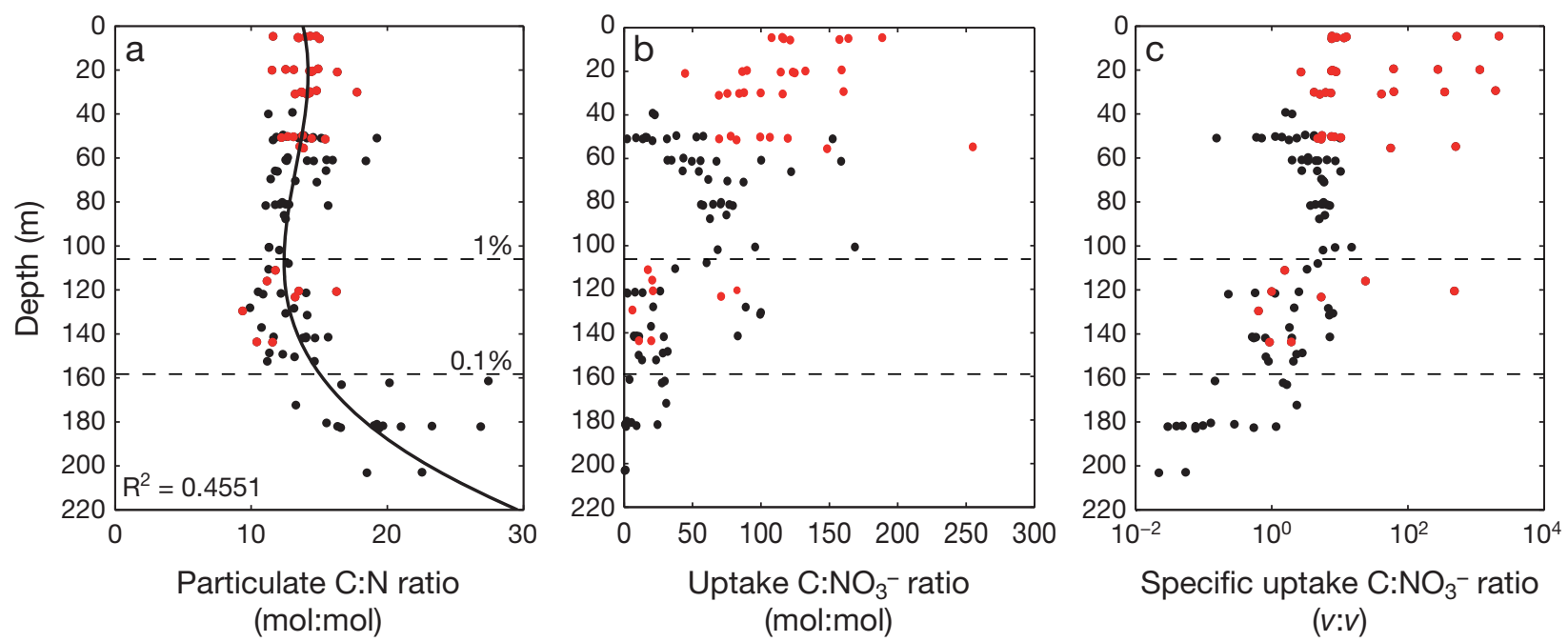

Fig. 5. Vertical profiles of (a) particulate C:N ratio, (b) uptake ratio of carbon to $\mathrm{NO}_{3}{ }^{-}$and (c) the specific uptake ratio of carbon to $\mathrm{NO}_{3}{ }^{-}$. Data were obtained during August and September 2011 and represent a combined dataset of lower euphotic zone incubations (black dots; 15 to $<0.1 \%$ surface irradiance, this study), and traditional euphotic zone incubations (red dots; 100 to $0.1 \%$ surface irradiance, discussed in Painter et al. 2013). The fitted line in (a) represents a cubic fit of form C:N ratio = $5.569 \mathrm{E}-06 \times \mathrm{depth}^{3}-0.00107 \times \mathrm{depth}^{2}+0.038 \times$ depth +13.804 


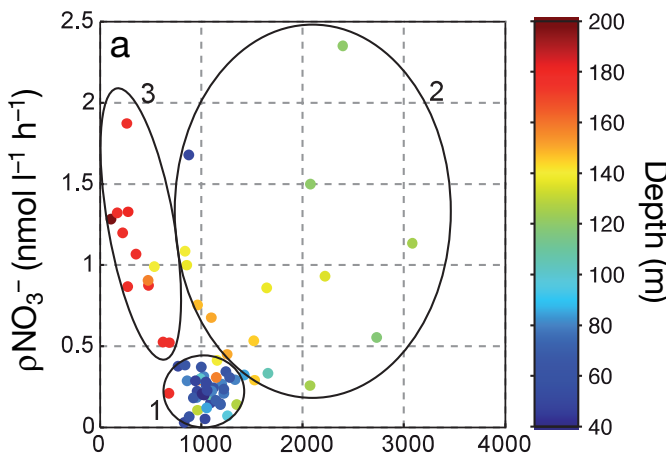

Picoeukaryote abundance (cells $\mathrm{ml}^{-1}$ )
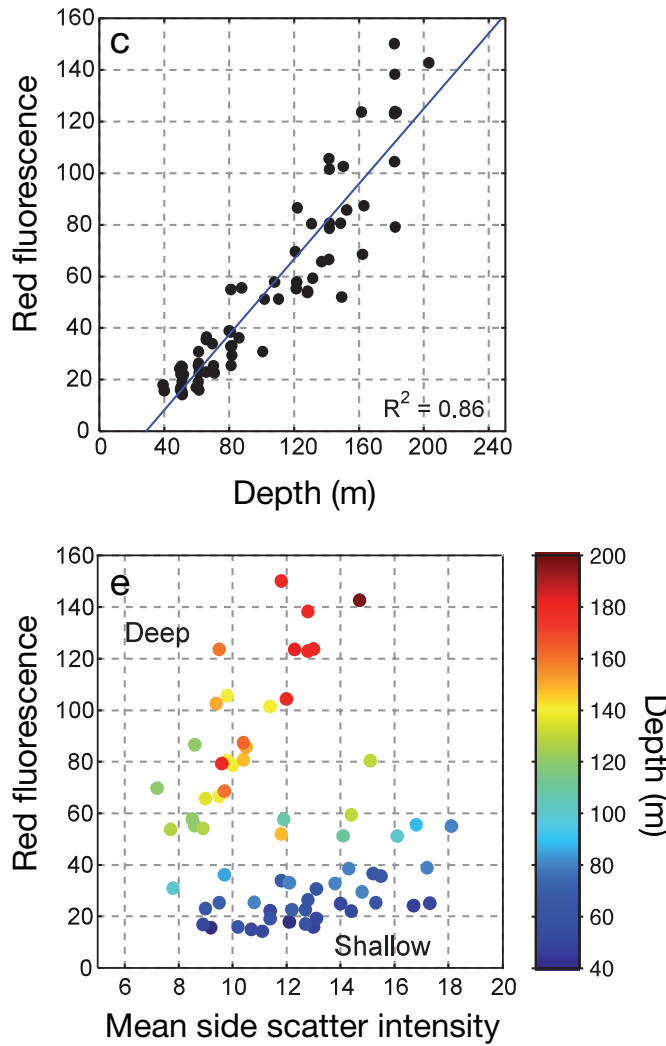

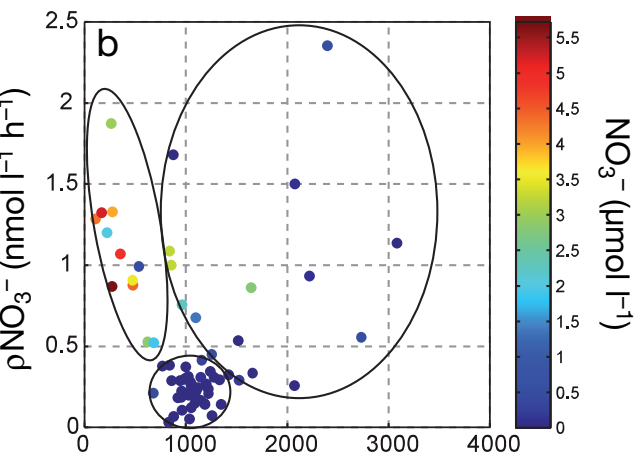

Picoeukaryote abundance (cells $\mathrm{ml}^{-1}$ )
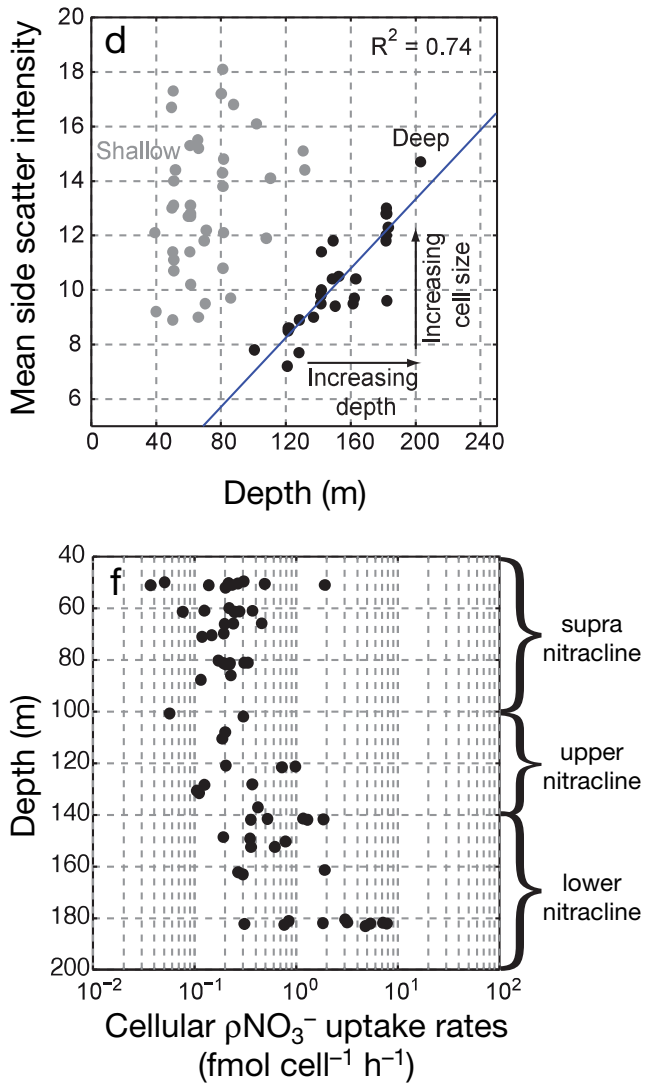

Fig. 6. Relationships between picoeukaryotic abundance and $\mathrm{NO}_{3}{ }^{-}$uptake in relation to (a) sampling depth (m) and (b) ambient $\mathrm{NO}_{3}{ }^{-}$concentration $\left(\mu \mathrm{mol} \mathrm{l^{-1 }}\right)$. The ovals in both subplots are used to identify 3 groups of data points indicative of supranitracline waters (Group 1), upper nitracline waters (Group 2) and lower nitracline waters (Group 3), which are characterised by distinct values or ranges of parameters (see 'Results' for details). Panels (c) and (d) show the relationships between red fluorescence and depth and mean side scatter and depth, respectively, for the picoeukaryote group; this information is combined in (e) to show the existence of 2 distinct subpopulations of picoeukaryotes. Panel (f) shows cell-normalized uptake rates

horizons in the upper ocean. Group 1, characterised by moderate picoeukaryote abundance $(\sim 1000$ cells $\left.\mathrm{ml}^{-1}\right)$, low $\mathrm{NO}_{3}^{-}$uptake $\left(<0.5 \mathrm{nmol} \mathrm{l}^{-1} \mathrm{~h}^{-1}\right)$ and low ambient $\mathrm{NO}_{3}{ }^{-}$concentrations $\left(<50 \mathrm{nmol} \mathrm{l}^{-1}\right)$ was representative of supra-nitracline waters (i.e. above the nitracline $;<100 \mathrm{~m}$ depth). Group 2, characterised by high picoeukaryote abundance (1000 to 3000 cells $\mathrm{ml}^{-1}$ ), high $\mathrm{NO}_{3}{ }^{-}$uptake (generally $>0.5 \mathrm{nmol} \mathrm{l}^{-1} \mathrm{~h}^{-1}$ ) and moderate ambient $\mathrm{NO}_{3}{ }^{-}$concentrations (50 to $500 \mathrm{nmol} \mathrm{l}^{-1}$ ) was representative of upper nitracline waters (i.e. the region where $\mathrm{NO}_{3}{ }^{-}$concentrations begin to increase rapidly; 100 to $140 \mathrm{~m}$ depth). Finally, Group 3, which was characterised by low picoeukaryote abundance $\left(<1000\right.$ cells $\left.\mathrm{ml}^{-1}\right)$, high $\mathrm{NO}_{3}{ }^{-}$up- 
take rates $\left(>0.5 \mathrm{nmol} \mathrm{l}^{-1} \mathrm{~h}^{-1}\right)$ and high ambient $\mathrm{NO}_{3}^{-}$ concentrations (>500 $\mathrm{nmol} \mathrm{^{-1 }}$ ) was typical of lower nitracline waters ( $>140 \mathrm{~m}$ depth). The similarity between the increased $\mathrm{NO}_{3}{ }^{-}$uptake with depth (as shown in Figs. 3a \& 4f) and the distribution of picoeukaryotic plankton is highly suggestive of a link between the two.

Analysis of the red fluorescence and side light scatter intensity signatures associated with picoeukaryotes indicated that deeper-living picoeukaryote cells had a significantly higher red fluorescence signature $\left(R^{2}=0.86\right)$, indicative of their higher chlorophyll content (due to photo-acclimation) than their shallower living counterparts (Fig. 6c). The mean side scatter intensity, which can be used as an indicator of cell size, revealed 2 well-defined assemblages (Fig. 6d,e). The shallow assemblage, which was generally representative of supra-nitracline waters, showed a wide range of side scattering intensities indicative of variable cell size but a weak relationship to depth. This assemblage is largely analogous to picoeukaryote Group 1. The deep assemblage meanwhile, showed a particularly strong relationship $\left(\mathrm{R}^{2}=0.74\right)$ of increased cell size with depth, and whilst not directly analogous, is predominately representative of picoeukaryote Groups 2 and 3. Thus, the picoeukaryotes overall showed increased red fluorescence with depth, and within the deeper of the 2 identified assemblages, cell size increased linearly with depth (Fig. 6e).

A further check of the assumptions under which we interpreted our results was gleaned from examination of picoeukaryote cell-normalized uptake rates (Fig. 6f). In the waters above $100 \mathrm{~m}$, cell-normalized uptake rates averaged $0.27 \pm 0.31 \mathrm{fmol} \mathrm{NO}_{3}^{-} \mathrm{cell}^{-1}$ $\mathrm{h}^{-1}$ but more generally were $<0.4 \mathrm{fmol} \mathrm{NO}_{3}^{-}$cell $^{-1}$ $\mathrm{h}^{-1}$. In the 100 to $140 \mathrm{~m}$ depth range typified by picoeukaryote Group 2, the average cellular uptake rate was higher at $0.6 \pm 1.07 \mathrm{fmol} \mathrm{NO}_{3}^{-} \mathrm{cell}^{-1} \mathrm{~h}^{-1}$, whilst at greater depths the cellular uptake rate was higher still at $1.96 \pm 2.25 \mathrm{fmol} \mathrm{NO}_{3}{ }^{-} \mathrm{cell}^{-1} \mathrm{~h}^{-1}$. In general, cell-normalized uptake rates appeared lowest above the nitracline but increased with depth therefore presumably in conjunction with increased $\mathrm{NO}_{3}{ }^{-}$concentrations. To provide a context for these rates we estimated cellular $\mathrm{N}$ content using the picoeukaryote cell biomass of $1496 \mathrm{fg} \mathrm{C}^{\mathrm{C}}$ cell $^{-1}$ and a C:N stoichiometry of 6.6 , which produced a cellular $\mathrm{N}$ content of $\sim 19 \mathrm{fmol} \mathrm{N}$ cell $^{-1}$. This indicated that our cell-normalized uptake rates were consistent with typical cellular $\mathrm{N}$ content and suggested that cellular $\mathrm{N}$ content could be turned over on timescales of $\sim 10$ to $\sim 70 \mathrm{~h}$. The increase in cell-normalized uptake rate with depth may be a function of picoeukaryote cell size, which, using side scatter as a proxy, increased with depth (Fig. 6d). Thus, biomass-normalized uptake rates may provide a better normalization metric. However, with the data we have available, and in particular the imposition of a fixed cell biomass relationship and uncertainty over cellular stoichiometric ratios (Frenette et al. 1998, Martiny et al. 2013), we were unable to test this further.

\section{DISCUSSION}

\section{Kinetics of $\mathrm{NO}_{3}{ }^{-}$uptake}

Our results demonstrate an important distinction between the waters of the nitracline and the supranitracline waters immediately above, and to further demonstrate the affinity for $\mathrm{NO}_{3}{ }^{-}$by deep-living plankton we derive the kinetic parameters related to $\mathrm{NO}_{3}{ }^{-}$uptake. At $\mathrm{NO}_{3}{ }^{-}$concentrations below $\sim 70 \mathrm{nmol} \mathrm{l}^{-1}, \mathrm{NO}_{3}{ }^{-}$uptake is generally considered a linear function of $\mathrm{NO}_{3}{ }^{-}$concentration rather than a hyperbolic function as described by the MichaelisMenten equation (McCarthy et al. 1992, Rees et al. 1999). At the 3 shallowest sampling horizons, $\mathrm{NO}_{3}{ }^{-}$ uptake was indeed more appropriately described via a linear relationship to $\mathrm{NO}_{3}{ }^{-}$concentration following a log transformation of the data (Fig. A1a-c in the Appendix). However, the ability of changes in $\mathrm{NO}_{3}{ }^{-}$ concentration alone to explain the variance in $\mathrm{NO}_{3}{ }^{-}$ uptake progressively diminished with depth - from explaining $71 \%$ of the variance at the shallowest horizon to $23 \%$ at the $5 \%$ irradiance depth. Using the same approach, Rees et al. (1999) determined that $83 \%$ of the variance in $\mathrm{NO}_{3}{ }^{-}$uptake in surface waters $(<30 \mathrm{~m})$ of the NE North Atlantic could be explained by changes in $\mathrm{NO}_{3}{ }^{-}$concentration. That the relationship between $\mathrm{NO}_{3}{ }^{-}$uptake and $\mathrm{NO}_{3}{ }^{-}$concentration weakened with depth, despite low and constant $\mathrm{NO}_{3}{ }^{-}$concentrations being found down to $\sim 100 \mathrm{~m}$, suggests that other controls on $\mathrm{NO}_{3}{ }^{-}$uptake, such as irradiance, became progressively more important. The coefficients for the equations describing the linear fits to the data (not shown) are broadly similar, and using the ordinate value of the last valid data point at each depth to determine the crossing point of the linear fit on the abscissa, all produced a positive intercept on the $x$-axis at $4 \mathrm{nmol}^{-1}$. In other words, the linearity of $\mathrm{NO}_{3}{ }^{-}$uptake with $\mathrm{NO}_{3}{ }^{-}$concentration extended down to a concentration of $4 \mathrm{nmol} \mathrm{l}^{-1}$ similar to the estimate of $5 \mathrm{nmol}^{-1}$ obtained by Rees et al. (1999). 
At deeper, more $\mathrm{NO}_{3}{ }^{-}$-rich sampling horizons, $\mathrm{NO}_{3}{ }^{-}$ uptake was better-defined by a Michaelis-Menten type relationship, though there was considerable scatter within the data (Fig. A1e-g in the Appendix). In the strictest sense, our data should not be used to establish uptake kinetics, as the phytoplankton community structure was variable in space and time and some of the scatter seen at these deeper irradiance horizons will reflect variations in both the abundance and composition of the community within our incubation bottles. It is nevertheless true that the data from the deeper sampling horizons did fit the Michaelis-Menten equation, suggesting that approximate kinetic parameters could be obtained. Consequently, at the deep chlorophyll maximum we estimated parameter values for maximum uptake $\left(V_{\max }\right)$ and for the half saturation constant $\left(K_{\mathrm{s}}\right)$ of $3 \mathrm{nmol} \mathrm{l^{-1 }}$ $\mathrm{h}^{-1}$ and $184 \mathrm{nmol} \mathrm{l}^{-1}$, respectively. At a depth of $0.5 \%$ PAR, $V_{\max }$ was determined to be $1.01 \mathrm{nmol}^{-1} \mathrm{~h}^{-1}$ and $K_{\mathrm{s}}$ was $498 \mathrm{nmol}^{-1}$, whilst at the deepest sampling depth values for $V_{\max }$ and $K_{\mathrm{s}}$ were $1.63 \mathrm{nmol} \mathrm{l}^{-1} \mathrm{~h}^{-1}$ and $2013 \mathrm{nmol} \mathrm{l}^{-1}$, respectively.

Because the data from supra-nitracline depths were broadly similar, we pooled the data together to obtain mean estimates of the kinetic parameters for the supra-nitracline waters. In doing this we were able to obtain estimates of $V_{\max }$ and $K_{\mathrm{s}}$ of $4.86 \mathrm{nmol}$ $\mathrm{l}^{-1} \mathrm{~h}^{-1}$ and $11.9 \mathrm{nmol} \mathrm{l^{-1 }}$, respectively, but 3 data points heavily weight the result (Fig. A1d in the Appendix). Nevertheless, these results are comparable to those reported by Rees et al. (1999) $\left(V_{\max }=\right.$ $2.77 \mathrm{nmol} \mathrm{l}^{-1} \mathrm{~h}^{-1}, K_{\mathrm{s}}=20 \mathrm{nmol} \mathrm{l}^{-1}$ ) and by Harrison et al. (1996) (WOCE-93 data, $V_{\max }=0.63 \mathrm{nmol} \mathrm{l}^{-1}$ $\mathrm{h}^{-1}, K_{\mathrm{s}}=27 \mathrm{nmol} \mathrm{l}^{-1}$ ) from the surface waters of the subtropical North Atlantic, lending credence to our estimates.

\section{A summary of $\mathrm{NO}_{3}{ }^{-}$uptake at the nitracline}

In Fig. 7, we present a summary of our observations, which represents a generic description of $\mathrm{NO}_{3}{ }^{-}$uptake at the nitracline and how the resident picoeukaryote-dominated phytoplankton community appears well-adapted to utilizing this deep nutrient source. Rate measurements, picoeukaryote abundance, $\mathrm{NO}_{3}^{-}$concentrations, C:Chl-a ratios and community growth rates from the 13 profiles reported here have been used to produce a mean vertical profile. The associated estimates of $V_{\max }$ and $K_{\mathrm{s}}$ for the plankton community are based on kinetics results obtained from the 6 sampled depth horizons (Fig. A1). Many of these parameters dis-
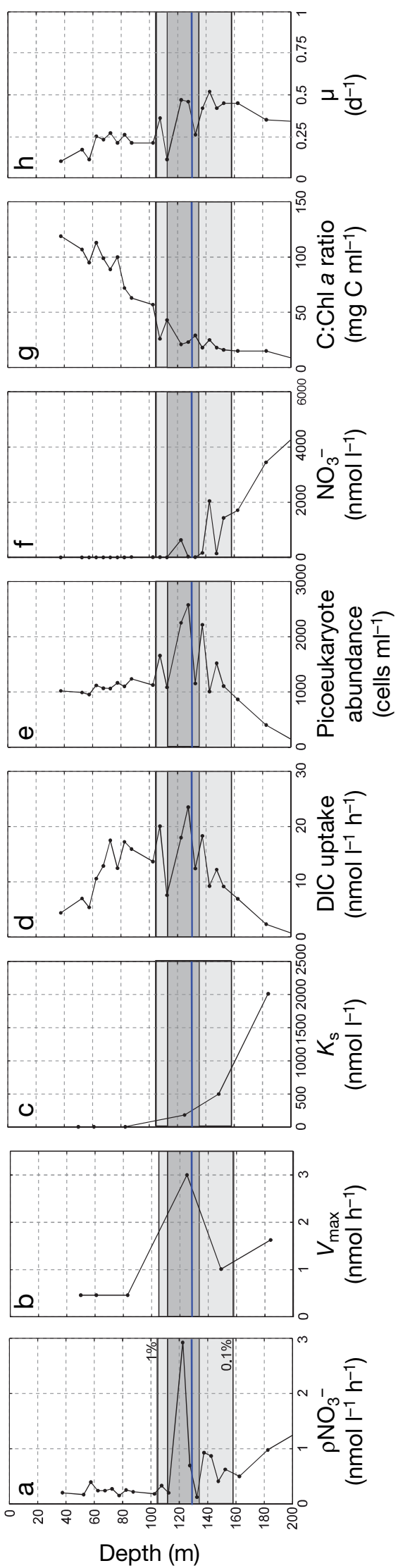
play co-located local maxima, and the prominent $\mathrm{NO}_{3}{ }^{-}$uptake maximum (Fig. 7a) was clearly associated with maximum picoeukaryote abundance (Fig. 7e), maximum community growth rate $\left(\sim 0.5 \mathrm{~d}^{-1}\right)$ (Fig. 7h), and a maximum in $V_{\max }$ (Fig. 7b). The maximum mean community growth rate of $0.52 \pm$ $0.18 \mathrm{~d}^{-1}$ observed at the nitracline is comparable to group-specific growth rates reported by Andre et al. (1999), which ranged from $0.42 \pm 0.13$ to $0.56 \pm$ $0.21 \mathrm{~d}^{-1}$ for picoeukaryotes and Synechococcus, respectively. More generally, the data reveal an increase in community growth rate with depth from $<0.25 \mathrm{~d}^{-1}$ at depths $<100 \mathrm{~m}$ to rates of $\sim 0.5 \mathrm{~d}^{-1}$ within the nitracline, a pattern that is consistent with that expected for a community increasingly dominated by small eukaryotic cells at depth (Lande et al. 1989). Our community-based growth rates are also in broad agreement with the conclusions reached by Marañón (2005) regarding low community growth rates in subtropical regions. In addition to changes in growth rate, the mean C:chl a ratio (Fig. $7 \mathrm{~g}$ ) exhibited a 4 -fold reduction, from values $>100$ at $50 \mathrm{~m}$ depth to values of $\sim 20$ at depths $>140 \mathrm{~m}$. The magnitude of this reduction was similar to the 3 to 6 -fold reduction reported by Perez et al. (2006); thus, our results are broadly reflective of typical conditions in the lower euphotic zone of the subtropical ocean.

One anomaly does, however, remain. At depths $>140 \mathrm{~m}$ there was a residual increase in the rate of $\mathrm{NO}_{3}{ }^{-}$uptake that does not appear to follow the trend in picoeukaryote abundance. This residual increase may be (1) related to a distinct subpopulation of picoeukaryotes and the gradual increase in picoeukaryote cell size found within this depth range (see Fig. 6d), (2) an artefact or (3) driven by processes that result in unusually high $\mathrm{C}: \mathrm{N}$ ratios in particulate material at depth (Fig. 5a). Further work on the picoplankton community in this depth range is needed to resolve this question, as the increase in the mean side scatter intensity and red fluorescence signature suggests important physiological adaptations are likely. In particular, the presence of ever larger but less numerous picoeukaryote cells at depths down to $200 \mathrm{~m}$ (and potentially deeper) raises many questions about the taxonomic composition, lifecycle and function of such organisms. Species diversity within the picoeukaryote group, which is poorly known, also requires further investigation in order to more fully describe and understand $\mathrm{NO}_{3}{ }^{-}$uptake at the top of, and within, the nitracline. This is likely to have important implications for understanding nutrient cycling in subtropical waters.

\section{Implications for the concept of a 2 layered euphotic zone}

The concept of a 2-layered euphotic zone with a productive upper layer based upon the rapid utilization of ammonium, urea or other organic nitrogen compounds and a less productive lower layer based increasingly on $\mathrm{NO}_{3}{ }^{-}$, is an established and widely used conceptual model for oligotrophic waters (e.g. Venrick 1982, Dore et al. 2008, Beckmann \& Hense 2009, Dave \& Lozier 2010). Unique floral assemblages associated with each layer further suggest that the biogeochemical role of each layer differs. It is notable that deep ocean sediment cores typically contain 'shade flora' species from the lower euphotic zone rather than species from the more productive upper water column (Molfino \& McIntyre 1990, Kemp \& Villareal 2013). Therefore, the upper layer may be important for the rapid synthesis and turnover of organic carbon and for air-sea gas exchange, whereas it is the lower layer that most likely regulates the flux of organic material to the ocean interior.

Our data revealed a significant co-location of maximum picoeukaryote abundance with maximum $\mathrm{NO}_{3}{ }^{-}$ uptake rates (Fig. 7), which we believe provides strong evidence to support the idea that $\mathrm{NO}_{3}{ }^{-}$uptake in the lower euphotic zone can be broadly linked to variability in the abundance of picoeukaryotic organisms (a plankton group that is far less common in the upper euphotic zone). However, the picoeukaryote community is highly diverse in oligotrophic systems (Kirkham et al. 2011, 2013) and identifying which of the many taxa are more likely to be responsible for the uptake of $\mathrm{NO}_{3}{ }^{-}$is not possible with the data available. Warranting further research, this study has documented the intriguing occurrence of $\mathrm{NO}_{3}{ }^{-}$uptake in the increasingly aphotic deeper waters (140 to $200 \mathrm{~m}$ ) of the subtropical ocean coincident with what appears to be a distinct picoeukaryote group (Group 3 in Fig. 6). We conjecture that this group may provide an explanation for the seasonal removal of $\mathrm{NO}_{3}{ }^{-}$beneath the euphotic zone in the North Pacific, reported by Johnson et al. (2010). Interestingly, in a global perspective on picoeukaryote community structure, Kirkham et al. (2013) reported the presence of Chrysophyceae and Trebouxiophyceae taxa to depths of $800 \mathrm{~m}$ in the Indian Ocean, which they ascribed to the mixotrophic potential of these taxa. If such taxa are indeed responsible for the uptake of $\mathrm{NO}_{3}{ }^{-}$beneath the euphotic zone then this would either expand the utility of the lower euphotic zone concept significantly, or more likely argue for the existence of a third (aphotic) layer; the role and function of which is unknown. 


\section{Implications for new and export production}

The consumption of $\mathrm{NO}_{3}{ }^{-}$at the base of, and even below, the euphotic zone represents an important decoupling of production from nutrient acquisition with implications for estimates of new production. The degree of plasticity in cellular and uptake C:N ratios at the base of the euphotic zone may be related to size-dependent (and species-specific) uptake rates under low irradiance. Hence, the imposition of fixed stoichiometric ratios when interpreting $\mathrm{NO}_{3}{ }^{-}$uptake and production rates at the base of the euphotic zone is likely inappropriate (Frenette et al. 1998, Martiny et al. 2013) and could impact estimates of new production based solely on $\mathrm{NO}_{3}{ }^{-}$removal. Furthermore, the non-migratory nature of picoeukaryotes implies that high $\mathrm{NO}_{3}{ }^{-}$uptake at depth is unlikely to be balanced by subsequent photosynthesis higher in the water column, as has been suggested for certain large and rare plankton (e.g. Villareal et al. 1996).

Phytoplankton community responses to nutrient input need not be visible within the upper euphotic zone-particularly if strong density gradients are present - as the biological impact may be entirely localized to the lower euphotic zone a few to tens of metres above the nitracline (Goldman \& McGillicuddy 2003). Our results, which show a 10 -fold increase in $\mathrm{NO}_{3}{ }^{-}$uptake rates with depth, also demonstrate a high affinity for $\mathrm{NO}_{3}{ }^{-}$within the picoeukaryote community, suggesting $\mathrm{NO}_{3}{ }^{-}$is likely to be rapidly consumed. Based on the derivation of kinetic parameter values (Fig. A1 and Fig. 7) the theoretical maximum rate of $\mathrm{NO}_{3}{ }^{-}$uptake at the uptake maximum was $3 \mathrm{nmol} \mathrm{l}^{-1} \mathrm{~h}^{-1}$, which is slightly higher than found in most individual profiles (Fig. 3a). Scaling to a daily rate and integrating over a $5 \mathrm{~m}$ thick layer results in a maximum daily uptake of $270 \mu \mathrm{mol} \mathrm{NO}{ }^{-} \mathrm{m}^{-2} \mathrm{~d}^{-1}$. Coincident estimates of the diffusive $\mathrm{NO}_{3}{ }^{-}$supply made during this cruise were over 4 -fold lower and averaged $60 \mu \mathrm{mol} \mathrm{m} \mathrm{m}^{-2} \mathrm{~d}^{-1}$ (Painter et al. 2013). The in situ demand for $\mathrm{NO}_{3}{ }^{-}$was thus significantly larger than the magnitude of the diffusive flux, which raises the possibility that small changes in the magnitude of $\mathrm{NO}_{3}{ }^{-}$uptake at depth may be a significant factor regulating the flux of $\mathrm{NO}_{3}{ }^{-}$to the upper euphotic zone. This supports the view put forward by Bienfang et al. (1984) and Banse (1987) that nutrient fluxes to the upper ocean are biologically regulated within the lower euphotic zone rather than due to physical processes alone. This mechanism is additional to density-driven stratification that separates the upper euphotic zone from deep ocean nutrient reservoirs, and may explain why only weak correlations between stratification and primary production have been found on interannual timescales (Dave \& Lozier 2010, Lozier et al. 2011).

Large eukaryotic phytoplankton are numerically rare in the open ocean but considered disproportionately important for export fluxes (Michaels \& Silver 1988). Smaller yet more numerous picoplankton are not generally thought to contribute directly to export fluxes due to their small cell size and negligible settling velocity (Takahashi \& Bienfang 1983, Michaels \& Silver 1988). However, this long-standing assumption has come under renewed scrutiny. Richardson \& Jackson (2007) found that picoplankton provide an important source of carbon to higher trophic levels and Lomas \& Moran (2011) reported a non-negligible contribution to export fluxes by aggregating picoplankton cells. Despite lower abundances, eukaryotic phytoplankton biomass is often equivalent to or exceeds that of the more numerous prokaryotic cells due to larger picoeukaryote cell size (Zubkov et al. 1998). As picoeukaryotes $(<2 \mu \mathrm{m})$ represented the dominant form of biomass in the broader $<12 \mu \mathrm{m}$ size class found between 150 and $200 \mathrm{~m}$ depth, they are most likely an attractive source of food for grazers as well as potentially acting as nuclei around which aggregates may form. We conjecture that picoeukaryotes most likely contribute to export fluxes by virtue of their deep-living nature and their biomass dominance deeper in the water column. In an environment where heterotrophic bacterial abundance decreases with depth and bacterial production rates at the nitracline are frequently $<30 \%$ of rates in the upper surface waters (Zubkov et al. 2000b), both factors could favour the export of picoeukaryote biomass. However, despite a clear and important role in $\mathrm{NO}_{3}{ }^{-}$uptake, understanding how picoeukaryotic production is translated into an exportable flux is not yet clear, and this remains important to the wider question of global rates of carbon export and the sensitivity of this export flux to changing environmental conditions. Predictions that the future ocean may experience stronger stratification, reduced vertical nutrient supply and an expansion of oligotrophic waters (e.g. Polovina et al. 2008, Gruber 2011) may not adversely impact picoeukaryote communities that appear well adapted to life at the nitracline, and such changes could even enhance the role they play in export production.

\section{CONCLUSIONS}

$\mathrm{NO}_{3}{ }^{-}$uptake rates within a thin layer of the upper nitracline were typically 10 -fold higher than uptake rates in the $\mathrm{NO}_{3}{ }^{-}$poor surface waters above. The 
decoupling of $\mathrm{NO}_{3}{ }^{-}$uptake at depth from a shallower primary production maximum is consistent with a reduced role for $\mathrm{NO}_{3}{ }^{-}$in sustaining upper euphotic zone productivity. Phytoplankton biomass at the nitracline was dominated by picoeukaryote phytoplankton whose maximum abundance was coincident with peak $\mathrm{NO}_{3}{ }^{-}$uptake rates. The in situ community was well adapted to life under low irradiance, as indicated by local growth rate maxima and mean rates of in situ $\mathrm{NO}_{3}{ }^{-}$uptake, which were similar to kineticbased estimates of maximum potential uptake rates.

Acknowledgements. We are grateful to Prof. Mike Zubkov for the invitation to participate in this cruise, to Ross Holland for assistance with the flow cytometry analyses and to Dave Spanner and Mike Bolshaw for their assistance with the isotopic analyses. We also thank the 4 reviewers for their detailed comments and close scrutiny of this manuscript. This cruise was supported by the Natural Environment Research Council through the Oceans 2025 research programme.

\section{LITERATURE CITED}

Agawin NSR, Duarte CM, Agusti S (2000) Nutrient and temperature control of the contribution of picoplankton to phytoplankton biomass and production. Limnol Oceanogr 45:591-600

> Andre JM, Navarette C, Blanchot J, Radenac MH (1999) Picoplankton dynamics in the equatorial Pacific: growth and grazing rates from cytometric counts. J Geophys Res 104(C2):3369-3380

Banse K (1987) Clouds, deep chlorophyll maxima and the nutrient supply to the mixed layer of stratified water bodies. J Plankton Res 9:1031-1036

Beckmann A, Hense I (2009) A fresh look at the nutrient cycling in the oligotrophic ocean. Biogeochemistry 96:1-11

Bienfang PK, Szyper JP, Okamoto MY, Noda EK (1984) Temporal and spatial variability of phytoplankton in a subtropical ecosystem. Limnol Oceanogr 29:527-539

Bronk DA, Ward BB (2000) Magnitude of dissolved organic nitrogen release relative to gross nitrogen uptake in marine systems. Limnol Oceanogr 45:1879-1883

> Bronk DA, Glibert PM, Ward BB (1994) Nitrogen uptake, dissolved organic nitrogen release and new production. Science 265:1843-1846

Casey JR, Lomas MW, Mandecki J, Walker DE (2007) Prochlorococcus contributes to new production in the Sargasso Sea deep chlorophyll maximum. Geophys Res Lett 34, L10604, doi:10610.11029/12006GL028725

Chisholm SW, Olson RJ, Zettler ER, Goericke R, Waterbury JB, Welschmeyer NA (1988) A novel free-living prochlorophyte abundant in the oceanic euphotic zone. Nature 334:340-343

> Coale KH, Bruland KW (1987) Oceanic stratified euphotic zone as elucidated by ${ }^{234} \mathrm{Th}:{ }^{238} \mathrm{U}$ disequilibria. Limnol Oceanogr 32:189-200

Collos Y, Slawyk G (1980) Nitrogen uptake and assimilation by marine phytoplankton. In: Falkowski PG (ed) Primary productivity in the sea. Plenum Press, Upton, NY, p 195-211

Cullen JJ (1982) The deep chlorophyll maximum: comparing vertical profiles of chlorophyll a. Can J Fish Aquat Sci 39: 791-803
Dave AC, Lozier MS (2010) Local stratification control of marine productivity in the subtropical North Pacific. J Geophys Res 115, C12032, doi:12010.11029/12010JC006507

de Boyer Montegut C, Madec G, Fischer AS, Lazar A, Ludicone D (2004) Mixed layer depth over the global ocean: an examination of profile data and a profile-based climatology. J Geophys Res 109, C12003, doi:12010.11029/12004 JC002378

Dore JE, Letelier RM, Church MJ, Lukas R, Karl DM (2008) Summer phytoplankton blooms in the oligotrophic North Pacific Subtropical Gyre: historical perspective and recent observations. Prog Oceanogr 76:2-38

> Dugdale RC, Wilkerson FP (1986) The use of $15 \mathrm{~N}$ to measure nitrogen uptake in eutrophic oceans; experimental considerations. Limnol Oceanogr 31:673-689

- Eppley RW, Koeve W (1990) Nitrate use by plankton in the eastern subtropical North Atlantic, March-April 1989. Limnol Oceanogr 35:1781-1788

Fawcett SE, Lomas MW, Casey JR, Ward BB, Sigman DM (2011) Assimilation of upwelled nitrate by small eukaryotes in the Sargasso Sea. Nat Geosci 4:717-722

Fouilland E, Gosselin M, Rivkin RB, Vasseur C, Mostajir B (2007) Nitrogen uptake by heterotrophic bacteria and phytoplankton in Arctic surface waters. J Plankton Res 29: 369-376

Frenette JJ, Vincent WF, Legendre L (1998) Size-dependent C:N uptake by phytoplankton as a function of irradiance: ecological implications. Limnol Oceanogr 43:1362-1368

Fuller NJ, Campbell C, Allen DJ, Pitt FD and others (2006) Analysis of photosynthetic picoeukaryote diversity at open ocean sites in the Arabian Sea using a PCR biased towards marine algal protists. Aquat Microb Ecol 43:79-93

Glover HE, Keller MD, Guillard RRL (1986) Light quality and oceanic ultraplankton. Nature 319:142-143

Glover HE, Keller MD, Spinrad RW (1987) The effects of light quality and intensity on photosynthesis and growth of marine eukaryotic and prokaryotic phytoplankton clones. J Exp Mar Biol Ecol 105:137-159

Glover HE, Prézelin BB, Campbell L, Wyman M, Garside C (1988a) A nitrate-dependent Synechococcus bloom in surface Sargasso Sea water. Nature 331:161-163

Glover HE, Prézelin BB, Campbell L, Wyman M (1988b) Picoand ultraplankton Sargasso Sea communities: variability and comparative distributions of Synechococcus spp. and algae. Mar Ecol Prog Ser 49:127-139

Goldman JC, McGillicuddy DJ Jr (2003) Effect of large marine diatoms growing at low light on episodic new production. Limnol Oceanogr 48:1176-1182

Coldman JC, McCarthy JJ, Peavey DG (1979) Growth rate influence on the chemical composition of phytoplankton in oceanic waters. Nature 279:210-215

> Grob C, Hartmann M, Zubkov MV, Scanlon DJ (2011) Invariable biomass-specific primary production of taxonomically discrete picoeukaryote groups across the Atlantic Ocean. Environ Microbiol 13:3266-3274

Gruber N (2011) Warming up, turning sour, losing breath: ocean biogeochemistry under global change. Philos Trans R Soc Lond A 369:1980-1996

> Harrison WG (1990) Nitrogen utilization in chlorophyll and primary productivity maximum layers: an analysis based on the f-ratio. Mar Ecol Prog Ser 60:85-90

Harrison WG, Harris LR, Irwin BD (1996) The kinetics of nitrogen utilization in the oceanic mixed layer: nitrate and ammonium interactions at nanomolar concentrations. Limnol Oceanogr 41:16-32

Hartmann M, Grob C, Tarran GA, Martin AP, Burkill PH, Scanlon DJ, Zubkov MV (2012) Mixotrophic basis of 
Atlantic oligotrophic ecosystems. Proc Natl Acad Sci USA 109:5756-5760

Hayward TL (1994) The shallow oxygen maximum layer and primary production. Deep-Sea Res I 41:559-574

> Jardillier L, Zubkov MV, Pearman J, Scanlan DJ (2010) Significant $\mathrm{CO}_{2}$ fixation by small prymnesiophytes in the subtropical and tropical northeast Atlantic Ocean. ISME J 4: 1180-1192

Johnson KS, Riser SC, Karl DM (2010) Nitrate supply from deep to near-surface waters of the North Pacific Subtropical Gyre. Nature 465:1062-1065

Karl DM, Laws EA, Morris P, Williams PJB, Emerson S (2003) Global carbon cycle: metabolic balance of the open sea. Nature 426:32

Kemp AES, Villareal TA (2013) High diatom production and export in stratified waters - a potential negative feedback to global warming. Prog Oceanogr 119:4-23

Kemp AES, Pike J, Pearce RB, Lange CB (2000) The 'fall dump' - a new perspective on the role of a 'shade flora' in the annual cycle of diatom production and export flux. Deep-Sea Res II 47:2129-2154

King FD, Devol AH (1979) Estimates of vertical eddy diffusion through the thermocline from phytoplankton nitrate uptake rates in the mixed layer of the eastern tropical Pacific. Limnol Oceanogr 24:645-651

Kirchman DL (1994) The uptake of inorganic nutrients by heterotrophic bacteria. Microb Ecol 28:255-271

Kirchman DL (2000) Uptake and regeneration of inorganic nutrients by marine heterotrophic bacteria. In: Kirchman DL (ed) Microbial ecology of the ocean. Wiley-Liss, New York, NY, p 261-288

Kirkham AR, Jardillier LE, Tiganescu A, Pearman J, Zubkov MV, Scanlan DJ (2011) Basin-scale distribution patterns of photosynthetic picoeukaryotes along an Atlantic Meridional Transect. Environ Microbiol 13:975-990

Kirkham AR, Lepere C, Jardillier LE, Not F, Bouman H, Mead A, Scanlan DJ (2013) A global perspective on marine photosynthetic picoeukaryote community structure. ISME J 7: 922-936

Kirkwood DS (1996) Nutrients: practical notes on their determination in seawater. ICES techniques in marine environmental sciences report 17. International Council for the Exploration of the Seas, Copenhagen

Lande R, Li WKW, Hornet EPW, Wood AM (1989) Phytoplankton growth rates estimated from depth profiles of cell concentration and turbulent diffusion. Deep-Sea Res 36: 1141-1159

Le Bouteiller A (1986) Environmental control of nitrate and ammonium uptake by phytoplankton in the Equatorial Atlantic Ocean. Mar Ecol Prog Ser 30:167-179

Letelier R, Karl DM, Abbott MA, Bidigare RR (2004) Light driven seasonal patterns of chlorophyll and nitrate in the lower euphotic zone of the North Pacific Subtropical Gyre. Limnol Oceanogr 49:508-519

Lewis MR, Harrison WG, Oakey NS, Herbert D, Platt T (1986) Vertical nitrate fluxes in the oligotrophic ocean. Science 234:870-873

Li WKW (1994) Primary production of prochlorophytes, cyanobacteria, and eucaryotic ultraplankton: Measurements from flow cytometric sorting. Limnol Oceanogr 39: 169-175

Lomas MW, Lipschultz F (2006) Forming the primary nitrite maximum: Nitrifiers or phytoplankton? Limnol Oceanogr 51:2453-2467

Lomas MW, Moran SB (2011) Evidence for aggregation and export of cyanobacteria and nano-eukaryotes from the Sargasso Sea euphotic zone. Biogeosciences 8:203-216
Longhurst AR, Harrison WG (1989) The biological pump: profiles of plankton production and consumption in the upper ocean. Prog Oceanogr 22:47-123

> Lozier MS, Dave AC, Palter JB, Gerber LM, Barber RT (2011) On the relationship between stratification and primary productivity in the North Atlantic. Geophys Res Lett 38, L18609, doi:10.1029/2011GL049414

Malmstrom RR, Coe A, Kettler GC, Martiny AC, Frais-Lopez J, Zinser ER, Chisholm SW (2010) Temporal dynamics of Prochlorococcus ecotypes in the Atlantic and Pacific Oceans. ISME J 4:1252-1264

Maranon E (2005) Phytoplankton growth rates in the Atlantic subtropical gyres. Limnol Oceanogr 50:299-310

- Marañón E, Holligan PM, Varela M, Mouriño B, Bale AJ (2000) Basin-scale variability of phytoplankton biomass, production and growth in the Atlantic Ocean. Deep-Sea Res I 47:825-857

Martiny AC, Kathuria S, Berube PM (2009a) Widespread metabolic potential for nitrite and nitrate assimilation among Prochlorococcus ecotypes. Proc Natl Acad Sci USA 106:10787-10792

Martiny AC, Tai APK, Veneziano D, Primeau F, Chisholm SW (2009b) Taxonomic resolution, ecotypes and the biogeography of Prochlorococcus. Environ Microbiol 11:823-832

> Martiny AC, Pham CTA, Primeau FW, Vrught JA, Moore JK, Levin SA, Lomas MW (2013) Strong latitudinal patterns in the elemental ratios of marine plankton and organic matter. Nat Geosci 6:279-283

> McCarthy JJ, Garside C, Nevins JL (1992) Nitrate supply and phytoplankton uptake kinetics in the euphotic layer of a Gulf Stream warm-core ring. Deep-Sea Res I 39(1A): S393-S403

Michaels AF, Silver MW (1988) Primary production, sinking fluxes and the microbial food web. Deep-Sea Res 35: 473-490

Molfino B, McIntyre A (1990) Precessional forcing of nutricline dynamics in the Equatorial Atlantic. Science 249:766-769

> Moore LR, Post AF, Rocap G, Chisholm SW (2002) Utilization of different nitrogen sources by the marine cyanobacteria Prochlorococcus and Synechococcus. Limnol Oceanogr 47:989-996

Moore CM, Mills MM, Arrigo KR, Berman-Frank I and others (2013) Processes and patterns of oceanic nutrient limitation. Nat Geosci 6:701-710

Mulholland MR, Lomas MW (2008) Nitrogen uptake and assimilation. In: D. Capone G, Bronk DA, Mulholland MR, Carpenter EJ (eds) Nitrogen in the marine environment (2nd edn). Academic Press, San Diego, CA, p 303-384

Murphy LS, Haugen EM (1985) The distribution and abundance of phototrophic ultraplankton in the North Atlantic. Limnol Oceanogr 30:47-58

> Ono S, Ennyu A, Najjar RG, Bates NR (2001) Shallow remineralization in the Sargasso Sea estimated from seasonal variations in oxygen, dissolved inorganic carbon and nitrate. Deep-Sea Res II 48:1567-1582

Paerl HW (2000). Marine plankton. In: Whitton BA, Potts M (eds) The ecology of cyanobacteria: their diversity in space and time. Kluwer, Dordrecht, p 121-148

> Painter SC, Sanders R, Poulton AJ, Woodward EMS, Lucas M, Chamberlain K (2007) Nitrate uptake at photic zone depths is not important for export in the subtropical ocean. Global Biogeochem Cycles 21, GB4005, doi:10.1029/2006 GB002807

Painter SC, Sanders R, Waldron HN, Lucas MI, Torres-Valdes S (2008) Urea distribution and uptake in the Atlantic Ocean between $50^{\circ} \mathrm{N}$ and $50^{\circ} \mathrm{S}$. Mar Ecol Prog Ser 368: $53-63$ 
Painter SC, Patey MD, Forryan A, Torres-Valdes S (2013) Evaluating the balance between vertical diffusive nitrate supply and nitrogen fixation with reference to nitrate uptake in the eastern subtropical North Atlantic Ocean. J Geophys Res 118:5732-5749,

Partensky F, Garczarek L (2010) Prochlorococcus: advantages and limits of minimalism. Annu Rev Mar Sci 2:305-331

Partensky F, Hess WR, Vaulot D (1999) Prochlorococcus, a marine photosynthetic prokaryote of global significance. Microbiol Mol Biol Rev 63:106-127

Patey MD, Rijkenberg MJA, Statham PJ, Stinchcombe MC, Achterberg EP, Mowlem M (2008) Determination of nitrate and phosphate in seawater at nanomolar concentrations. Trends Analyt Chem 27:169-182

Patey MD, Achterberg EP, Rijkenberg MJA, Statham PJ, Mowlem M (2010) Interferences in the analysis of nanomolar concentrations of nitrate and phosphate in oceanic waters. Anal Chim Acta 673:109-116

Perez V, Fernandez E, Maranon E, Anxelu X, Moran G, Zubkov MV (2006) Vertical distribution of phytoplankton biomass, production and growth in the Atlantic subtropical gyres. Deep-Sea Res I 53:1616-1634

- Polovina JJ, Howell EA, Abecassis M (2008) Ocean's least productive waters are expanding. Geophys Res Lett 35, L03618, doi:10.1029/2007GL031745

Poulton AJ, Holligan PM, Hickman A, Kim YN and others (2006) Phytoplankton carbon fixation, chlorophyll biomass and diagnostic pigments in the Atlantic Ocean. Deep-Sea Res II 53:1593-1610

Prézelin BB, Glover HE, ver Hoven B, Steinberg D and others (1989) Blue-green light effects on light-limited rates of photosynthesis: relationship to pigmentation and productivity estimates for Synechococcus populations from the Sargasso Sea. Mar Ecol Prog Ser 54:121-136

Raimbault P (1986) Effect of temperature on nitrite excretion by three marine diatoms during nitrate uptake. Mar Biol 92:149-155

Redfield AC (1958) The biological control of chemical factors in the environment. Am Sci 46:205-221

Redfield AC, Ketchum BH, Richards FA (1963) The influence of organisms on the composition of sea-water. In: Hill MN (ed) The sea Vol 2: composition of seawater comparative and descriptive oceanography. Interscience, London, p 26-77

Rees A, Woodward M, Joint I (1999) Measurement of nitrate and ammonium uptake at ambient concentrations in oligotrophic waters of the North-East Atlantic Ocean. Mar Ecol Prog Ser 187:295-300

Richardson TL, Jackson GA (2007) Small phytoplankton and carbon export from the surface ocean. Science 315: $838-840$

Riser SC, Johnson KS (2008) Net production of oxygen in the subtropical ocean. Nature 451:323-325

Scanlan DJ, Post AF (2008) Aspects of marine cyanobacterial nitrogen physiology and connection to the nitrogen cycle. In: Capone DG, Bronk DA, Mulholland MR, Carpenter EJ (eds) Nitrogen in the marine environment (2nd edn). Academic Press, San Diego, CA, 1073-1195

Slawyk G, Collos Y, Auclair J (1977) The use of the ${ }^{13} \mathrm{C}$ and ${ }^{15} \mathrm{~N}$ isotopes for the simultaneous measurement of carbon and nitrogen turnover rates in marine phytoplankton. Limnol Oceanogr 22:925-932

Small LF, Knauer GA, Tuel MD (1987) The role of sinking fecal pellets in stratified euphotic zones. Deep-Sea Res 34: 1705-1712

Smith SV, Kimmerer WJ, Walsh TW (1986) Vertical flux and biogeochemical turnover regulate nutrient limitation of net organic production in the North Pacific Gyre. Limnol Oceanogr 31:161-167

Takahashi M, Bienfang PK (1983) Size structure of phytoplankton biomas and photosyntheis in subtropical Hawaiian waters. Mar Biol 76:203-211

> Tarran GA, Heywood JL, Zubkov MV (2006) Latitudinal changes in the standing stocks of nano- and picoeukaryotic phytoplankton in the Atlantic Ocean. Deep-Sea Res II 53:1516-1529

Venrick EL (1982) Phytoplankton in an oligotrophic ocean: observations and questions. Ecol Monogr 52:129-154

Venrick EL (1988) The vertical distributions of chlorophyll and phytoplankton species in the North Pacific central environment. J Plankton Res 10:987-998

Villareal TA, Altabet MA, Culver-Rymsza K (1993) Nitrogen transport by vertically migrating diatom mats in the North Pacific Ocean. Nature 363:709-712

Villareal TA, Woods S, Moore JK, Culver-Rymsza K (1996) Vertical migration of Rhizosolenia mats and their significance to $\mathrm{NO}_{3}{ }^{-}$fluxes in the central North Pacific Gyre. J Plankton Res 18:1103-1121

- Villareal TA, Pilskaln C, Brzezinski M, Lipschultz F, Dennett M, Gardner GB (1999) Upward transport of oceanic nitrate by migrating diatom mats. Nature 397:423-425

> Ward BB, Kilpatrick KA, Renger EH, Eppley RW (1989) Biological nitrogen cycling in the nitracline. Limnol Oceanogr 34:493-513

Waterbury JB, Watson SW, Guillard RRL, Brand LE (1979) Widespread occurrence of a unicellular, marine, planktonic, cyanobacteria. Nature 277:293-294

- Welschmeyer NA (1994) Fluorometric analysis of chlorophyll $\mathrm{a}$ in the presence of chlorophyll $\mathrm{b}$ and phaeopigments. Limnol Oceanogr 39:1985-1992

- Wheeler PA, Kirchman DL (1986) Utilization of inorganic nitrogen by bacteria in marine systems. Limnol Oceanogr 31:998-1009

Wood AM (1985) Adaptation of photosynthetic apparatus of marine ultraplankton to natural light fields. Nature 316: 253-255

Worden AZ, Not F (2008) Ecology and diversity of picoeukaryotes. In: Kirchman DL (ed) Microbial ecology of the oceans (2nd edn). John Wiley \& Sons, Hoboken, NJ, 159-205

Zubkov MV, Tarran GA (2008) High bacterivory by the smallest phytoplankton in the North Atlantic Ocean. Nature 455: $224-226$

- Zubkov MV, Sleigh MA, Tarran GA, Burkhill PH, Leakey RJG (1998) Picoplankton community structure on an Atlantic transect from $50^{\circ} \mathrm{N}$ to $50^{\circ} \mathrm{S}$. Deep-Sea Res I 45 : 1339-1355

Zubkov MV, Sleigh MA, Burkill PH (2000a) Assaying picoplankton distribution by flow cytometry or underway samples collected along a meriodional transect across the Atlantic Ocean. Aquat Microb Ecol 21:13-20

Zubkov MV, Sleigh MA, Burkill PH, Leakey RJG (2000b) Bacterial growth and grazing loss in contrasting areas of North and South Atlantic. J Plankton Res 22:685-711

Zubkov MV, Sleigh MA, Burkill PH, Leakey RJG (2000c) Picoplankton community structure on the Atlantic Meridional Transect: a comparison between seasons. Prog Oceanogr 45:369-386

Zubkov MV, Fuchs BM, Tarran GA, Burkhill PH, Amann R (2003) High rate of uptake of organic nitrogen compounds by Prochlorococcus cyanobacteria as a key to their dominance in oligotrophic oceanic waters. Appl Environ Microbiol 69:1299-1304 

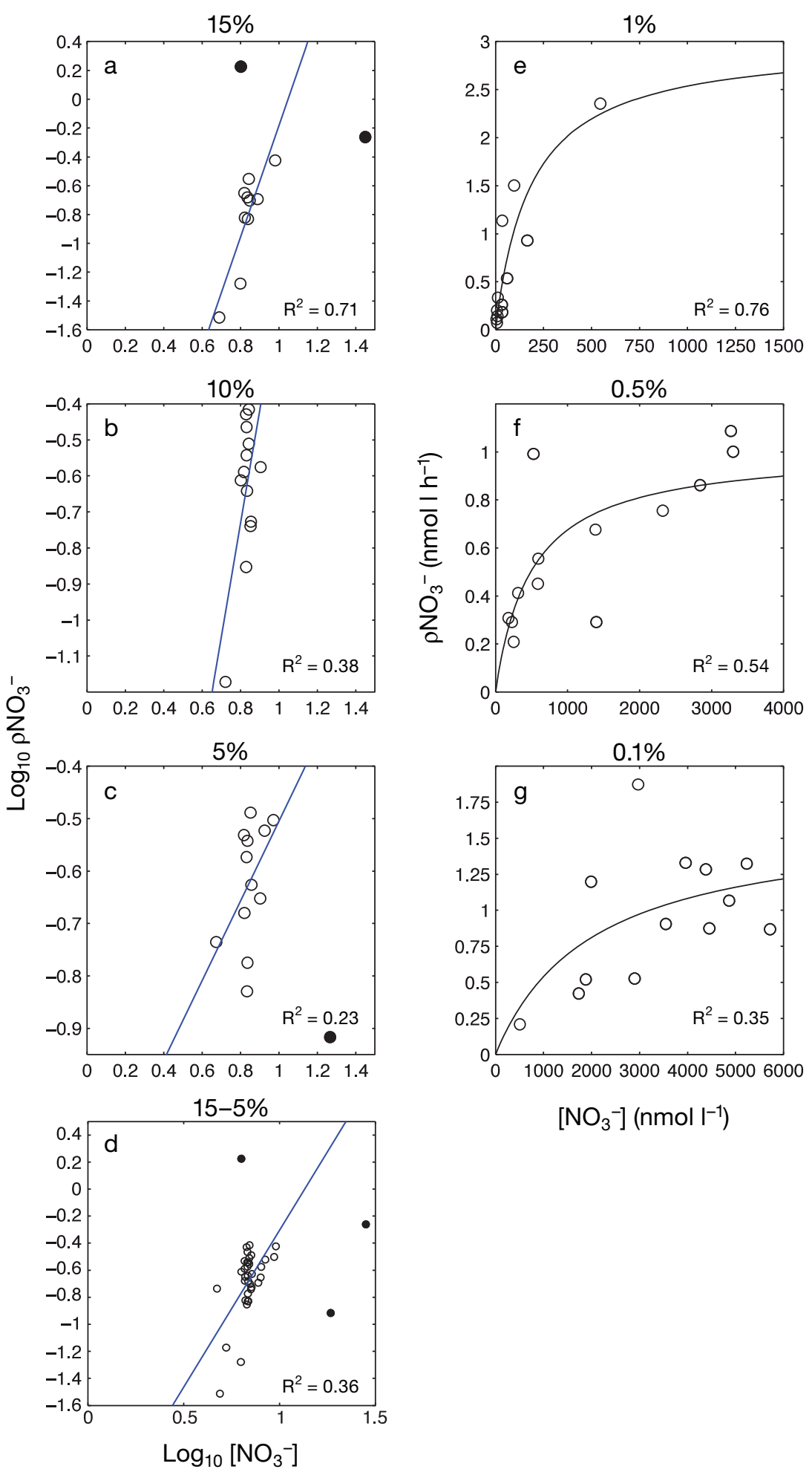

Appendix. Fig. A1. Kinetics curves presented by irradiance horizon based on pooled samples from all experiments. The left hand column shows the log-transformed relationship between $\mathrm{NO}_{3}{ }^{-}$uptake $\left(\mathrm{\rho NO}_{3}{ }^{-}\right)$and ambient $\mathrm{NO}_{3}{ }^{-} \mathrm{Concentrations} \mathrm{for}^{-}$ depths corresponding to (a) $15 \%$ surface irradiance, (b) $10 \%$ surface irradiance, (c) $5 \%$ surface irradiance and (d) a combined dataset representing all data collected between 15 and $5 \%$ surface irradiance. A linear trend (blue line) is fitted to each dataset with data points excluded from the fit shown in black. The right hand column shows results (on untransformed data) from the 3 nitracline/sub-nitracline depths corresponding to (e) $1 \%$ surface irradiance, (f) $0.5 \%$ surface irradiance and (g) $0.1 \%$ surface irradiance. A best fit Michaelis-Menten curve is shown by the black line 